\title{
Exploring possible links between Quaternary aggradation in the Upper Rhine Graben and the glaciation history of northern Switzerland
}

\author{
Frank Preusser $^{1}$ (D) Matthias Büschelberger ${ }^{1,2} \cdot$ Hans Axel Kemna $^{1,3} \cdot$ Johannes Miocic $^{1,4} \cdot$ Daniela Mueller $^{1}$. \\ Jan-Hendrik May ${ }^{1,5}$
}

Received: 12 August 2020 / Accepted: 1 May 2021 / Published online: 16 May 2021

(c) The Author(s) 2021

\begin{abstract}
The Quaternary filling of the Upper Rhine Graben is an excellent archive to reconstruct sediment dynamics in response to climate change, in particular related to past glaciations of the Swiss Alpine Foreland. Here, a sediment sequence recovered by drilling for exploration purposes near Kronau is investigated, using a combination of sedimentological logging, provenance studies (heavy minerals and clast petrography), and luminescence dating. Several phases of coarse sediment aggradation are identified that possibly correlate to Marine Isotope Stages (MIS) 12 (478-424 ka), 10 (374-337 ka), 8 (300-243 ka), 6 (191-130 ka) and/or 4 (71-57 ka), and 2 (29-14 ka). Several of these phases have previously also been reported from cores recovered in the major Quaternary depo-centre near Heidelberg. This suggests that the observed coarse aggradation in the Upper Rhine Graben can be assigned to various glaciations in northern Switzerland: Möhlin (MIS 12), Habsburg (MIS 10 or 8), Beringen (MIS 6), an unnamed glacial advance during MIS 4, and Birrfeld (MIS 2). However, due to the limited data available, this hypothesis and the suggested correlations require further confirmation by applying the approach presented here to further cores from the Upper Rhine Graben.
\end{abstract}

Keywords Upper Rhine Graben · Quaternary · Fluvial sediment · Provenance $\cdot$ Heavy mineral analyses · Luminescence dating

\section{Introduction}

During the Quaternary, changes of the Earth orbital parameters induced climate modifications with led to temporally widespread glaciations in large parts of the planet (e.g.,

Frank Preusser

Frank.preusser@geologie.uni-freiburg.de

1 Institute of Earth and Environmental Sciences, University of Freiburg, Albertstr. 23b, 79104 Freiburg im Breisgau, Germany

2 Present Address: Fraunhofer Institute for Mechanics of Materials, 79104 Freiburg im Breisgau, Germany

3 Present Address: Ucon Geoconsulting, Uhlenhorst 51, 47803 Krefeld, Germany

4 Present Address: Energy and Sustainability Research Institute, University of Groningen, Groningen, The Netherlands

5 Present Address: School of Geography, Earth \& Atmospheric Sciences, University of Melbourne, Parkville, Australia
Ehlers and Gibbard 2007). In addition to major impacts on the biosphere, this caused substantial changes in geo-processes on the Earth surface. For example, physical weathering and glacial erosion during cold periods produced a major increase of debris available to the sedimentary systems, with important degradation of mountain ranges and debris flux into the foreland (e.g., Leeder et al. 1998). While this phenomenon has been studied intensely for the Alps and its related drainage network (e.g., Hinderer 2001), several questions remain open with regard to the exact timing of Quaternary glaciations and their impact on fluvial systems. For the Eastern Alps, van Husen and Reitner (2011) follow the scheme of Penck and Brückner (1901-09) and identify four major glaciations during the Middle and Late Pleistocene (Günz, Mindel, Riss, Würm). In contrast, Preusser et al. (2011) discuss evidence for a maximum of eight glaciations during the Early Pleistocene (2580-770 ka; 'Deckenschotter Glaciations') and at least four, possibly even seven glacial advances reaching the Swiss lowlands during the Middle and Late Pleistocene ( $<500 \mathrm{ka})$. However, deciphering the 
glacial stratigraphy in different parts of the foreland of the Alps is hampered by the fact that the sedimentary record is often incomplete in proximal positions. A better preservation potential of depositional sequences is to be expected for subsiding basins in more distal parts of the sediment routing systems (e.g., Nádor et al. 2003; Garzanti et al. 2011; Gabriel et al. 2013).

One such subsiding basin is the Upper Rhine Graben (URG), located to the NW of the Alps. Since its formation, it acts as the major depo-centre of erosional debris originating from the Western (Swiss) Alps as well as from the Jura, the Black Forest, and the Vosges mountains (Fig. 1). Hence, analysing the Quaternary sedimentary record of the URG can contribute to an improved understanding of the environmental history of the entire region, when glaciations triggered major erosion in the above-mentioned mountain ranges with related debris transfer into the graben. Besides the scientific interest in understanding past environments and sculpturing of the Earth surface, unravelling the glaciation history is also relevant for applied aspects such as the stratigraphic architecture and resulting hydrogeological conditions in the URG that supplies more than three million people in France and Germany with drinking water (e.g., Thierion et al. 2012).

Presented here are the results of investigating an $80 \mathrm{~m}$ long sediment core drilled nearby Kronau, SW Germany. We first provide a short review of the general scheme of sedimentary dynamics and the Cenozoic history of the URG,
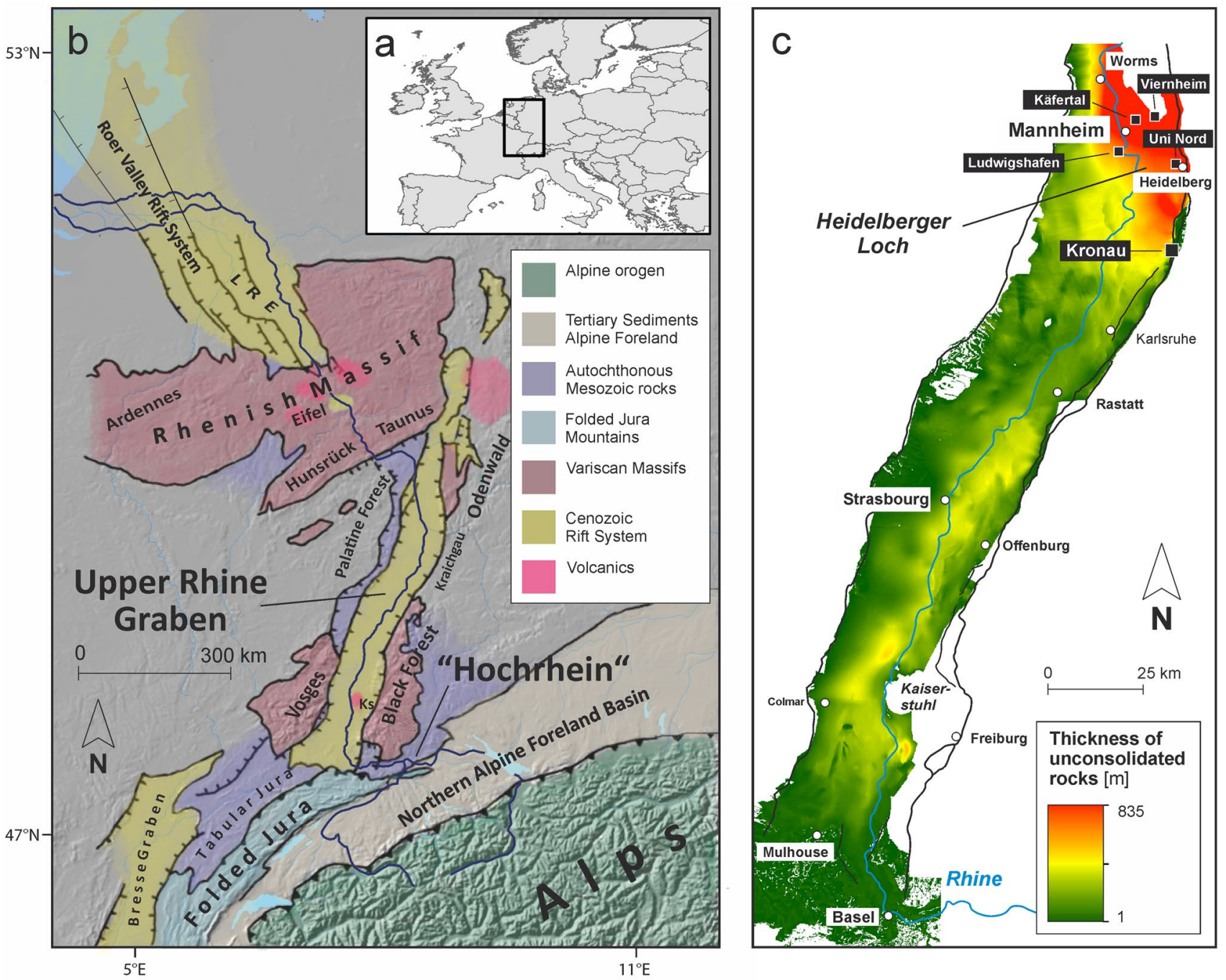

Fig. 1 a Location of the European Cenozoic Drift System. b Overview of the geological context of the Upper Rhine Graben. Data source: SRTM 2007 and GTOPO30 HYDRO1K 2000. Ks Kaiserstuhl, LRE Lower Rhine Embayment. $\mathbf{c}$ Map showing the thickness of unconsolidated sediments and the location of key drilling sites of the Heidelberg Basin Drilling Project (Heidelberg Uni Nord, Käfertal, Ludwigshafen, Viernheim) as well as the position of the Kronau borehole that is investigated in this study (sediment thickness after GeoORG-Projektteam 2013) 
followed by summarising the lithostratigraphy of the core with petrographic analyses, and the results of luminescence dating that were used to constrain the ages of depositional phases. The latter topic requires detailed attention as some of the sediments are close to the upper dating limit of the method. The observations are compared with evidence from the Heidelberg Basin Drilling Project (e.g., Gabriel et al. 2013), and are discussed in the context of regional glaciations and related sediment dynamics. This study is a further step towards understanding the complex Plio-Pleistocene sedimentary architecture of the URG. Previous studies have mainly relied on lithostratigraphic approaches, were the timing of changes is not of first-order importance and had a focus limited to the URG itself. Presented here is the first attempt to link Quaternary aggradation in the URG to the chronology of glaciations in Switzerland, which has been the main source of debris supply throughout the Quaternary. Potential correlations with marine isotope stratigraphy and glacial records outside the drainage area are also discussed, by this placing the observations from the URG in a wider environmental context.

\section{Geology of the Upper Rhine Graben}

\section{Tectonic context}

The URG is a $350 \mathrm{~km}$ long and up-to $50 \mathrm{~km}$ wide SSW-NNE striking basin structure and part of the European Cenozoic Rift System that stretches from the Mediterranean Sea via the Rhône-Bresse Graben towards the Lower Rhine Embayment (Ziegler 1994; Fig. 1a). The shoulders of the URG are formed by an uplifted Variscian basement with mainly Mesozoic sediment cover, in particular the Lower Triassic ('Buntsandstein'). The eastern side of the graben shoulder forms the Black Forest and the Odenwald that are separated by the Kraichgau Depression. The western graben shoulder comprises the Vosges and Palatinate Forest (Fig. 1b). Upstream, the URG is connected to the Alpine foreland through the Hochrhein Valley that follows the margin of the Jura Mountains and the Black Forest from East to West. The northern edge of the URG is represented by the triple junction of the Mainz Basin and borders the Rhenish Massif.

Rifting and associated deposition in the graben started in Middle Eocene times (e.g., Illies 1974; Hüttner 1991) and lasts until today (e.g., Peters and van Balen 2007; Weidenfeller and Kärcher 2008). During the Late Neogene, the tectonic stress field was modified from E-W (parallel rifting) to NE-SW (oblique rifting), which led to a sinistral transpressional tectonic movement (Illies 1977; Laubscher 2001; Giamboni et al. 2004). This modern stress field has largely controlled the distribution and thickness of sediments within the graben, including erosion on uplifted tectonic blocs within the graben and at its shoulders (GeORG-Projektteam 2013). The maximum thicknesses of more than $800 \mathrm{~m}$ of Plio-Pleistocene sediments occurs within the Heidelberg Basin (Bartz et al. 1982; GeORG-Projektteam 2013; Fig. 1c). Around Heidelberg, Cenozoic sediments reach a total thickness of more than $4000 \mathrm{~m}$ (GeORG-Projektteam 2013), of which more than $500 \mathrm{~m}$ are attributed to the Quaternary (Gabriel et al. 2013).

\section{Sedimentary system}

The URG is affected by regional to local-scale tectonic movements that determine available accommodation space and can modify the surface gradient (Gabriel et al. 2013). In addition, the volume and grain-size of debris supplied from upstream reaches of the River Rhine and its tributaries as well as the capacity to route this debris through the URG is directly and indirectly affected by climate-related factors, such as, among others, discharge variability, weathering intensity, and vegetation density. These factors have varied during the Quaternary and the longer-term sedimentary dynamics can be described by the variation between two endmembers, an overall depositional mode, and an overall incisional mode.

During the depositional mode, the headwaters are glaciated and the origin of the entire Rhine system (i.e., the origin of glacial meltwater discharge and debris release) shifts from the Alps towards the Jura Mountains, hence to a more proximal position with regard to the URG. Related to this mode is a high debris supply to the system from physical weathering (frost shattering) on unglaciated slopes, in combination with increased subglacial bedrock erosion and/or reworking of older unconsolidated sediments. This way, ice flow related to glacial advances delivers large quantities of dominantly coarse (sand and gravel) and poorly rounded clasts from the Alps to the foreland and the proximal drainage network that emerges from the glacier terminus.

This depositional mode is best characterised by the last major ice advance that lasted from ca. 30 to $18 \mathrm{ka}$ (Preusser et al. 2011; Gaar et al. 2019). Temperature reconstructions from northern Switzerland for the time just preceding the onset of the last glaciation indicate mean summer temperatures between $8{ }^{\circ} \mathrm{C}$ and $12{ }^{\circ} \mathrm{C}$, whereas mean winter temperatures have been estimated to between $-21^{\circ} \mathrm{C}$ and $-14{ }^{\circ} \mathrm{C}$ (Jost-Stauffer et al. 2001). This is supported by reconstructions from the adjacent Alpine foreland of eastern France with mean July temperatures of about $9{ }^{\circ} \mathrm{C}$ for the period $30 \mathrm{ka}$ to $18 \mathrm{ka}$ (Ampel et al. 2010), implying strong and likely long winters with limited water availability, alternating with summers warm enough to produce substantial amounts of meltwater. Consequently, during such times the river system must have been characterised by high debris load, short-lived pulses of high flow related to meltwater 
events, but limited long-term transport capacity. Glaciofluvial outwash deposits of braided river style, related to such conditions, have been investigated in detail in the Hochrhein Valley (Fig. 1c) and the southernmost part of the URG (Siegenthaler and Huggenberger 1993; Huggenberger and Regli 2006; Kock et al. 2009). These comprise mainly pool, channel, and sheet flow deposits, whereas floodplain and bar deposits are mostly absent and were likely eroded by high discharge events associated to a laterally dynamic channel system (Siegenthaler and Huggenberger 1993). As the Hochrhein Valley is restricted to a maximum width of a few kilometres, it represents a bottleneck for debris throughpass. This caused accumulation of up to $30 \mathrm{~m}$ of sediment in the Hochrhein Valley during the last glaciation, and the development of a fan-like structure at the southern edge of the URG, reflecting the strong climate- and glacier-driven aggradation tendency. Aggradation also dominated the fluvial system downstream over the entire length of the URG with a trend of decreasing medium and maximum grain-size from the south (mainly gravel) towards the north (mainly sand) (Kock et al. 2009; Przyrowski and Schäfer 2015).

In contrast, the incisional mode is characterised by rather low debris supply to the fluvial system, caused, firstly, by low production on the hillslopes (less pronounced frost shattering) and decreased connectivity and transfer to the drainage pathway (due to a dense vegetation cover) during warmer climate. Secondly, most coarse debris is stored in peri-Alpine lakes (e.g., Lake Constance) that formed at the end of the glacial period, forming a major sink for debris originating from the Alps (Hinderer 2001). Hence, further downstream in the URG, the fluvial system has a high transport capacity, in particular during the transition from the glacial mode when large quantities of meltwater are available from decaying ice.

Until the onset of human interference in the nineteenth century, the entire URG fluvial system was in the incisional mode and characterised by erosion of sediment deposited during the preceding glacial periods. The result was a maximum of $30 \mathrm{~m}$ of steplike, vertical incision in the Hochrhein area (Kock et al. 2009), located just upstream of the URG, and still ca. $5 \mathrm{~m}$ of incision in the Mainz Basin, which is located ca. $300 \mathrm{~km}$ to the north (Erkens et al. 2009). In the southern part of the URG, this caused the dynamic redistribution of substantial amounts of coarse fluvial sediment since the Late Glacial, well documented by radiocarbondated oak trunks and luminescence-dated sediments of braided river style, reflecting generally high debris load (Kock et al. 2009). With the declining influence of sediment redistribution and the lower valley gradient further downstream, the River Rhine adopted anastomosing channel patterns that gradually change to a meandering style further north. Here, the glacial aggradation surface formed across the entire width of the URG but is mainly preserved as remnants of the Low Terrace near the graben shoulders today (Erkens et al. 2009). This terrace comprises sandy and gravelly channel sediments deposited by a braided river, expressing the distal facies of the outwash deposits. Stepwise incision into this terrace level is still difficult to constrain accurately with regard to timing but must have started after ca. $20 \mathrm{ka}$ in the northern URG (Dambeck 2005).

The fact that a terrace sequence developed both in the Hochrhein/southern URG area and in the northern URG/ Mainz Basin is not fully understood, as correlations remain uncertain. Nevertheless, a combination of allogenic and autogenic controlling factors and site-specific characteristics such as preservation potential and tectonic background situation has been generally suggested as a potential explanation (Erkens et al. 2009). In fact, a spatially discontinuous and temporally non-uniform scenario for incision in the URG seems highly plausible given that (i) erosional thresholds in the various parts of the URG can be expected to vary with changing grain-size and gradient across the length of the URG, and (ii) downstream debris supply, and thus transport capacity, is directly coupled to sediment remobilisation further upstream. The entire system is further modified by erosion and debris supply from tributaries of different volume and with catchment characteristics with regard to size, gradient, bedrock geology etc.

Regardless of the detailed progression of the erosional history along the URG, aggradation across the entire width of the graben structure (perpendicular to the graben axis) during the last glaciation suggests that a model linking upstream glaciation in the Alps with pronounced pulses of aggradation in the URG should also be valid for preceding glaciations. Periods of incision and tectonic movements undoubtedly had an influence on the preservation potential of older sediments and, thus, the overall Quaternary stratigraphic framework of the URG is likely discontinuous in most parts of the graben. As a consequence, preservation of older glaciofluvial deposits related to Pleistocene glaciations will likely be limited to strongly subsiding areas, such as the Heidelberg Basin, and a range of locations close to the graben shoulders.

\section{Sedimentary filling}

Given the tectonic setting, geologic research in the URG mainly relies on geophysical and borehole data (e.g., Przyrowski and Schäfer 2015). Using a hydrogeological approach, Bartz et al. (1982) established a simple stratigraphic scheme of Plio-Pleistocene deposits distinguishing between coarse (aquifers) and fine layers (aquitards; Fig. 2). In this scheme, the coarse gravel layers are assigned to cold (glacial) climatic conditions (braided rivers), while the finegrained layers are expected to represent interglacial conditions (meandering rivers sensu lato). Sediment-petrographic 


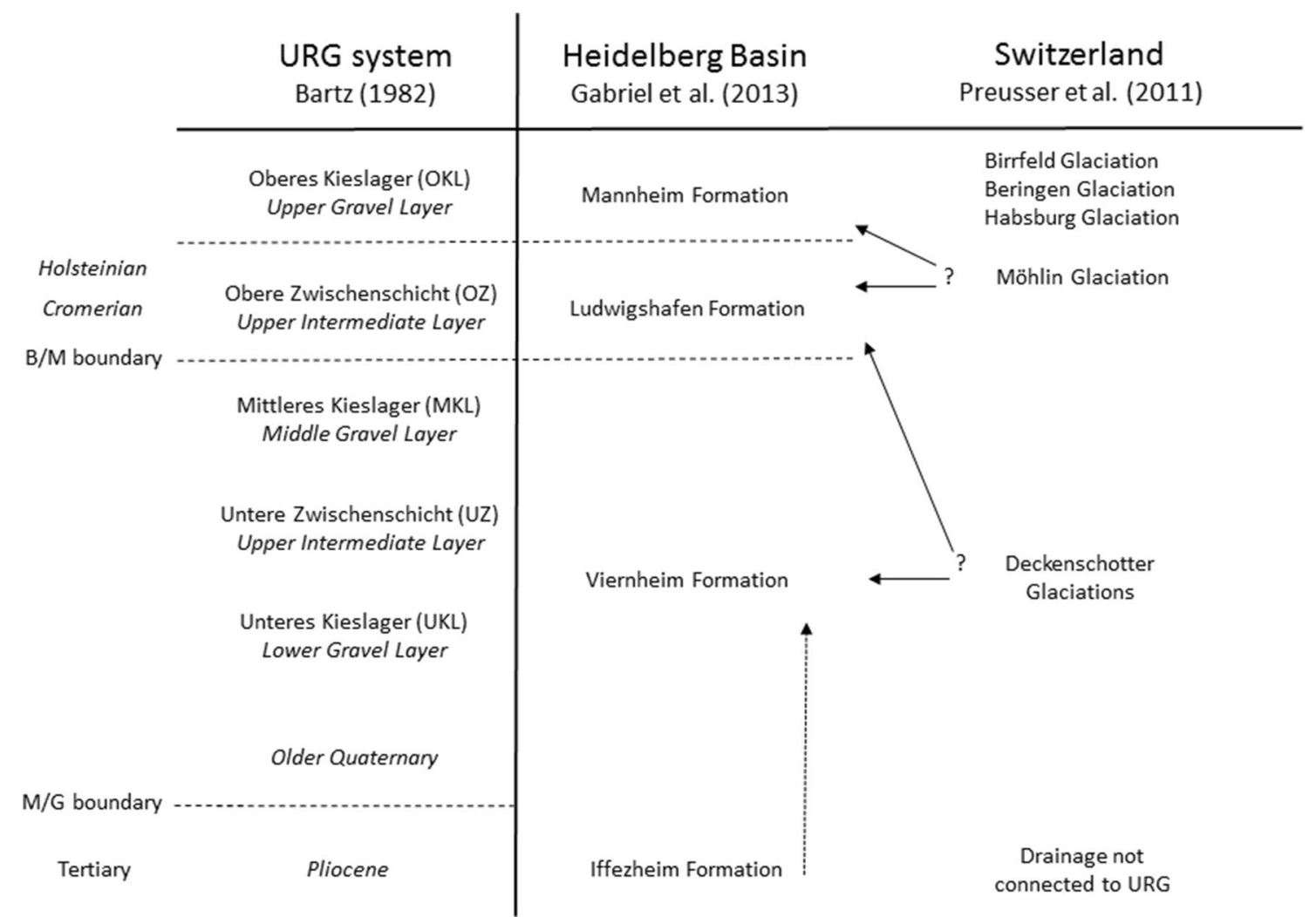

Fig. 2 Stratigraphic schemes established for the URG compared to the glaciation record of northern Switzerland. Please note that the system by Gabriel et al. (2013) was developed for the Heidelberg Basin and does not reflect the stratigraphy of the southern and north-

investigations based on heavy mineral analysis show that most of the Pliocene graben fill was derived from the graben shoulders (Hagedorn and Boenigk 2008). A distinct shift in heavy mineral assemblages indicates the connection of the Alpine Rhine/Aare system to the URG during the Latest Pliocene (Boenigk 1987). This is in accordance with general observations regarding the fluvial history of the entire Rhine/Aare system (Petit et al. 1996; Boenigk and Frechen 2006; Kemna 2008; Preusser 2008).

A more recent integrated approach led to the formal definition of lithostratigraphic units for the URG (Ellwanger et al. 2003; LithoLex 2011; Fig. 2). The initial scheme was developed further during the Heidelberg Basin Drilling Project that investigated scientific boreholes at Heidelberg, Ludwigshafen, and Viernheim (Gabriel et al. 2008, 2013; LGRB 2012; Fig. 1c). The lowermost Plio-Pleistocene formation in the entire URG (Iffezheim Formation), is characterised by carbonate-free gravel and fine-grained sediments of nonAlpine provenance, usually bleached and with a kaolinitic matrix (Hagedorn and Boenigk 2008). All along the URG this basal unit is overlain by carbonate-bearing clastics of Alpine origin or at least mixed Alpine and local provenance. Only in marginal positions and in deeply incised valleys of ern parts of the URG. B/M=Brunhess/Matuyama; M/G= Matuyama/ Gauss magnetic boundaries (after Scheidt et al. 2015). The position of the Holsteinian is based on Hahne et al. (2012) and is discussed in the text

the graben shoulders the Quaternary debris may lack Alpine input and is, in this case, then also carbonate free (Ellwanger et al. 2012). In the southern URG the Iffezheim Formation is overlain by the coarse-grained Breisgau and Neuenburg Formations. These regularly (but not always) show typical Rhenish Facies heavy mineral assemblages with a predominance of garnet, epidote and alterite, accompanied by the Alpine marker mineral green hornblende. In the northern URG, deposits above the Iffezheim Formation are represented by the Viernheim and Mannheim Formations, likewise usually bearing a Rhenish Facies of heavy minerals. In the Heidelberg Basin, these sediments are separated by finer-grained sediments of the Ludwigshafen Formation. In intermediate positions, sediments of the Iffezheim Formation are overlain by only one lithostratigraphical unit of medium-grained, mixed Alpine and local gravel termed Ortenau-Formation. Correlation of the southern and northern stratigraphic units is not straightforward. This is due to, firstly, the decreased preservation of Alpine material with progressive transport distance and, at the same time, the relative increase of local debris input. Secondly, the influence of tectonic block movement on the deposition pattern also increases towards the north (GeORG-Projektteam 2013). 


\section{Chronology of Quaternary deposition}

The Iffezheim Formation is mainly characterised by containing Tertiary to Early Pleistocene ('Tiglian') pollen assemblages (Gabriel et al. 2013). However, in the core Ettenheim even Middle Pleistocene pollen assemblages have been observed (Weidenfeller and Knipping 2008; Hahne et al. 2012). Heavy mineral assemblages are of local origin, an input from the Alps is lacking (Hagedorn and Boenigk 2008). In the Heidelberg Basin, Scheidt et al. (2015) interpret that the top of this formation belongs to the geomagnetic Gauss Chron (3.56-2.58 Ma). However, the differentiation of the Iffezheim Formation from stratigraphically younger units is based on provenance rather than age (Ellwanger et al. 2012). Pollen assemblages of the overlying Viernheim Formation imply a correlation with the Early to Middle Pleistocene (Ellwanger et al. 2008; Knipping 2008; Gabriel et al. 2013). According to Scheidt et al. (2015) the BrunhesMatuyama (B/M) magnetic boundary, recently consistently dated to $772 \pm 7 \mathrm{ka}$ (Valet et al. 2018) and $776 \pm 14 \mathrm{ka}$ (Ghaleb et al. 2019), is located in the upper-most part of the Viernheim Formation. Palynological investigations of fragmentary sequences have allocated the Holsteinian Interglacial (ca. 424-374 ka; cf. Lauer and Weiss 2018) to the upper part of the Ludwigshafen Formation, whereas the middle and lower part are likely of Cromerian age (Ellwanger et al. 2008; Hahne et al. 2012; Gabriel et al. 2013). Accordingly, the Mannheim Formation would comprise the final part of the Middle as well as the entire Late Pleistocene. Consistently, Menzies and Ellwanger $(2012,2015)$ deduced from mircomorphological analyses that the Mannheim Formation shows clear indications of, at least, four distinct climate changes.

As a direct geochronological approach, luminescence dating has been applied to the Viernheim core (Fig. 1c), where Lauer et al. (2010) identify a major phase of aggradation within the Mannheim Formation correlating to Marine Isotope Stage (MIS) 4-3 (ca. 60-40 ka). Li et al. (2018) confirm this age of the upper Mannheim Formation in the Heidelberg core based on two quartz ages. As most Middle Pleistocene sediments are beyond the dating limit of quartz, Lauer et al. (2011) applied infrared radiofluorescence (IR-RF) to feldspars yielding ages between $288 \pm 19 \mathrm{ka}$ and $643 \pm 28 \mathrm{ka}$. However, Li et al. (2018) state that these ages are underestimated due to signal loss (fading). Instead, Li et al. (2018) used the post Infrared-Infrared Stimulated Luminescence (pIR) protocol, in which Infrared Stimulated Luminescence is first stimulated at $50{ }^{\circ} \mathrm{C}$ (IRSL or IR-50) followed by a second stimulation at $225^{\circ} \mathrm{C}$ (pIR-225). In storage tests, $\mathrm{Li}$ et al. (2018) observed signal loss for both IR-50 and pIR-225 that was corrected using two fading correction models. By this, ages of 400-500 ka were determined for the middle and upper part of the Ludwigshafen Formation.
Interestingly, none of the cores from the Heidelberg Basin (Fig. 1c) reveal directly dated evidence for deposition during the latest part of the Middle Pleistocene (MIS 6; ca. 185-130 ka). This period is expected to represent a major glaciation of the Alps, known as Rissian (e.g., Doppler et al. 2011; Ellwanger et al. 2011; van Husen and Reitner 2011) but named Beringen in Switzerland (Graf 2009; Preusser et al. 2011). This extensive glaciation should have led to increased debris flux into the URG. The question regarding the presence of MIS 6 deposits will have implications regarding the sedimentary architecture in the entire URG, in particular as local tectonics will have played an important role with regard to sediment accumulation and preservation (Ellwanger et al. 2008). However, while the Viernheim sequence seems to imply the absence of MIS 6 deposits (Lauer et al. 2010, 2011; Gabriel et al. 2013), there are yet undated sections in both the Heidelberg (Uni Nord 1) and Ludwigshafen (P34) cores. Altogether, these recent observations challenge the simple and generalised model commonly used in applied geology (Bartz et al. 1982; Fig. 2) and imply that further sediment cores with solid chronology are needed from around the URG towards a more complete understanding of the complex pattern of Quaternary sedimentation.

\section{Study site}

The core presented and analysed in this study was extracted near Kronau, located close to the eastern margin of the northern URG. The site is located just about $20 \mathrm{~km}$ south of the southernmost borehole of the Heidelberg Basin Drilling Project (Fig. 1b). The tectonic setting of the Kronau area comprises a complex mosaic of distinct blocks, and the thicknesses of Plio-Pleistocene deposits can vary considerably over short distances (Bartz et al. 1982). Hahne et al. (2012) report palynological analyses on two cores (MKL/04 and GWM M3) located near Kronau, about 2300 and $3000 \mathrm{~m}$ from the drillsite of the core presented here, respectively, but both located on another tectonic block with stronger subsidence during the Pleistocene (Ellwanger et al. 2012). Borehole MKL/04 reached a total depth of $136 \mathrm{~m}$ within sediments assigned to the Viernheim Formation that bear pollen assemblages below $84 \mathrm{~m}$ depth that have been assigned to the Bavel Complex, which represents an Early Pleistocene period comprising several warm phases (Zagwijn 1985, 1992). Pollen samples from borehole GWM M3 (total depth $35 \mathrm{~m}$, Ludwigshafen Formation) showed assemblages assigned to the Holsteinian Interglacial at a depth between 26.2 and $25 \mathrm{~m}$. Further down-section, sediments are interpreted to be of Cromerian age (32.0-34.7 m) based on palynology. 


\section{Methods}

\section{Logging and laboratory analyses}

Drilling was carried out for exploration purposes in April 2007 within the gravel pit of Klaus Reimold Gmbh in Bad Schönborn near Kronau (R: 3,473,145, H: 5,452,487, $110.8 \mathrm{~m}$ ) to a final depth of $80 \mathrm{~m}$ (LGRB archive number 6717-1249). The recovered core material was stored in protective wooden boxes on location after the drilling. Logging was carried out in February 2016 on-site following EN ISO 14688-1:2002. Besides standard grainsize classification, the maximum grain diameter ( $b$-axis) in each metre was recorded. Furthermore, for the gravel and coarse sand fraction roundness was assessed (class 1: very angular, 2: angular, 3: subangular, 4: subrounded, 5: rounded, 6: well rounded). Carbonate content was estimated using $10 \% \mathrm{HCl}$ (no reaction = carbonate free; weak reaction $=$ carbonate bearing; strong and lasting reaction $=$ high carbonate content). Samples were taken for further laboratory analyses, including determination of drycolour using Munsell soil charts. In addition, petrography was semi-quantitatively estimated for the gravel fraction.

For grain-size analyses, wet-sieving following standard procedures was carried out for the sand and gravel fraction (sieves: $16 \mathrm{~mm}, 8 \mathrm{~mm}, 6.3 \mathrm{~mm}, 4 \mathrm{~mm}, 2 \mathrm{~mm}$, $1 \mu \mathrm{mm}, 630 \mu \mathrm{m}, 400 \mu \mathrm{m}, 200 \mu \mathrm{m}, 125 \mu \mathrm{m})$. Large clasts $(>16 \mathrm{~mm})$ were measured by hand (b-axis), whereas the fraction $<125 \mu \mathrm{m}$ (fine fraction: fine sand and mud) was not further distinguished for the majority of samples. Ten samples were prepared and analysed for heavy mineral content following Boenigk (1983), by counting 100 transparent mineral grains.

\section{Luminescence dating}

Luminescence dating utilises a signal in quartz and feldspar grains that is erased (bleached) during daylight expose and accumulates during burial through the interaction of ionising radiation with the crystal lattice (cf. Preusser et al. 2008). The method comprises a series of approaches that target signals with different bleachability and stability. For dating, the amount of radiation absorbed by the mineral grains since deposition (Equivalent Dose: $D_{e}$ ) is quantified through comparison with laboratory-induced radiation. The second value to be determined for age calculation is the dose rate, i.e. the level of radiation in the natural environment of the sample. This is mainly derived from the concentration of naturally occurring radioactive elements $(\mathrm{K}, \mathrm{Th}, \mathrm{U})$, but is modified by other factors such as sediment moisture (cf. Preusser et al. 2008).
Quartz Optically Stimulated Luminescence (OSL) has the advantage that the signal resets fast and is stable over geological timescales. The disadvantage is that quartz from some regions shows problematic signal properties, in particular when derived from freshly weathered crystalline rocks (Preusser et al. 2009). Indeed, previous studies from the middle URG have reported problematic behaviour of quartz (Lauer et al. 2010; Preusser et al. 2016). Feldspar usually emits strong IRSL signals but the signal resets slightly slower than quartz OSL, i.e. it requires longer daylight exposure, hence a longer transport path. IRSL often also shows instability over geological time periods, a phenomenon named anomalous fading (cf. King et al. 2018). The problem of fading can be reduced or even eliminated by applying a second elevated temperature readout after the first IRSL (IR-50) measurement (cf. Li et al. 2014). This technique is called post-IR IRSL (pIR) and comprises different approaches using different stimulation temperatures; the higher the stimulation temperature, the more stable the signal but at the cost of the time required to reset the signal. Furthermore, high thermal treatment may change the samples' IRSL sensitivity and cause incorrect $D_{\mathrm{e}}$ assessments (e.g., Chen et al. 2013). In summary, while luminescence dating has a high potential to enlighten the depositional history of the URG, the method is associated with several problems. It is hence feasible to compare different luminescence approaches in one study to evaluate the reliability of the dating results.

In this study, sampling for luminescence dating was carried out on the sandy parts of the cores that appeared undisturbed and where the material was presumably directly transferred from the drill-head into the wooden boxes. Limited preservation prevented sampling of some parts that appeared interesting to date from the stratigraphic point of view. During the night and by using red-headlights, the selected sections were sampled after removal of the outermost $5 \mathrm{~cm}$ of sediment, and obtained material was transferred to the laboratory using light-proof bags. Preparation for $\mathrm{D}_{\mathrm{e}}$ measurement included sieving (100-150 $\mu \mathrm{m})$, removal of carbonates $(10 \% \mathrm{HCl})$ and organic material $\left(30 \% \mathrm{H}_{2} \mathrm{O}_{2}\right)$, as well as density separation of a quartz and feldspar fraction using heavy liquids (Na-polytungstate). The quartz fraction was etched in $40 \% \mathrm{HF}(1 \mathrm{~h})$, to remove the remaining feldspar and the outer rim of the quartz grains, followed by $10 \% \mathrm{HCl}$ treatment ( $>1 \mathrm{~h}$, to dissolve fluorites). In this study, quartz OSL was used together with two pIR protocols, one using stimulation of $225^{\circ} \mathrm{c}$ (pIR-225) and the other stimulation at $290{ }^{\circ} \mathrm{C}$ (pIR-290). $\mathrm{D}_{\mathrm{e}}$ was determined by modified Single Aliquot Regenerative Dose (SAR) protocols for both quartz and feldspar (Table 1) using a Lexsyg Smart device (Richter et al. 2015).

For quartz, we observe substantial problems with signal properties, i.e. low OSL response and/or evidence for 
Table 1 SAR protocol used in this study. (1) omitted during first cycle; (2) stimulation with blue light (458 $\mathrm{nm}$ LED, $50 \mathrm{~mW} \mathrm{~cm}{ }^{-3}$ ) at $125^{\circ} \mathrm{C}$ for $35 \mathrm{~s}$; detection window centred at $365 \mathrm{~nm}$ : Hoya U-340 filter $(2.5 \mathrm{~mm})$ in combination with a Delta BP 365/50 EX-Interfer- ence filter (5 mm); (3) stimulation with IR light (850 nm LED, 230 $\mathrm{mW} \mathrm{cm}{ }^{-3}$ ) $120 \mathrm{~s}$; detection window centred at $410 \mathrm{~nm}$ : Schott BG39 filter ( $3 \mathrm{~mm}$ ) in combination with AHF BrightLine HC 414/46 Interference filter $(3.5 \mathrm{~mm})$

\begin{tabular}{llll}
\hline Step & Quartz OSL & pIR-225 & pIR-290 \\
\hline 1 & Regeneration dose (1) & Regeneration dose (1) & Regeneration dose (1) \\
2 & Preheat at $230{ }^{\circ} \mathrm{C}$ for $10 \mathrm{~s}$ & Preheat at $250^{\circ} \mathrm{C}$ for $10 \mathrm{~s}$ & Preheat at $250{ }^{\circ} \mathrm{C}$ for $10 \mathrm{~s}$ \\
3 & OSL measurement (2) & IRSL (3) at $50^{\circ}($ IR-50) & IRSL (3) at 50 $($ IR-50) \\
4 & Test dose & IRSL (3) at $225^{\circ}(\mathrm{pIR}-225)$ & IRSL (3) at 290 $(\mathrm{pIR}-225)$ \\
5 & Preheat at $230^{\circ} \mathrm{C}$ for $10 \mathrm{~s}$ & Test dose & Test dose \\
6 & IRSL (3), only last cycle & Preheat at $250^{\circ} \mathrm{C}$ for $10 \mathrm{~s}$ & Preheat at $250{ }^{\circ} \mathrm{C}$ for $10 \mathrm{~s}$ \\
7 & OSL measurement (2) & IRSL (3) at $50^{\circ}$ & IRSL (3) at $50^{\circ}$ \\
8 & Start new cycle & IRSL (3) at $225^{\circ}$ & IRSL (3) at $290^{\circ}$ \\
9 & & Start new cycle & Start new cycle \\
\hline
\end{tabular}


Fig. 3 Examples of typical luminescence characteristics of the samples. a Poorly behaving quartz OSL with different decay shape of natural and irradiated signal as well as (inset) significant signal depletion during the IR test. b Well-behaving quartz OSL with similar natural and irradiated OSL decay; (inset) dose-response is almost linear. a

feldspar contamination (Fig. 3a). The latter is detected by the IR-depletion test integrated into the SAR protocol (Duller 2003) and the majority of measured aliquots had to be and $\mathbf{b}$ are two representative aliquots of KRN2Q. $\mathbf{c}$ Strong pIR-225 response as recorded for KRN9F. The dose-response (inset) curve approaches but does not reach saturation. d Response of pIR-290 with the natural (inset) being higher than the apparent laboratory saturation level of KRN9F

discarded accordingly. Only for sample KRN2Q a sufficient number of aliquots with well-behaving OSL signals could be accepted (10 out 80 measured; Fig. $3 \mathrm{~b}$ ). As screening 
indicated that quartz is in saturation for the samples taken below $13 \mathrm{~m}$, we obtained only one OSL age for the entire sequence. Contrarily, feldspar shows a strong signal response (Fig. 3c, d). The applied procedure returns two age estimates for each of the applied protocols, one for the initial IRSL measurement at $50{ }^{\circ} \mathrm{C}$ (IR-50) and one for the following second stimulation at elevated temperature (pIR). For the three samples from the upper part of the sequence (KRN13), 24 aliquots were measured for pIR-225. Considering the good reproducibility, the number of replicate measurements was reduced to 12 for pIR-290. For samples from the lower part of the core (KRN4-9), we had to further reduce the number of replicates to nine for pIR-225 and to three for pIR-290 (these are all in saturation). For the dose-response curves, we applied fitting using the sum of two exponential saturating functions, as this best describes the shape of the curves. $D_{\mathrm{e}}$ values of all samples are below $2 D_{0}$, a measure of signal saturation, which implies samples should be in the range of dating (Wintle and Murray 2006). Due to the presence of narrow and Gaussian-like $D_{\mathrm{e}}$ distributions with quite low overdispersion (Fig. 4), the Central Age Model (CAM, Galbraith et al. 1999) as used for calculation of mean $D_{\mathrm{e}}$ for all approaches but pIR-290 (see below).

A series of experiments were carried out to characterise the performance of the different luminescence signals and by this contributing towards examining the reliability of the dating results. In dose recovery experiments, it is tested how well the measurement procedure can reproduce a laboratory given radiation dose. For this purpose, samples were exposed to an Osram Ultra-Vitalux (UV) lamp for $100 \mathrm{~h}$ to remove the inherent luminescence signal in the feldspar grains. Samples were then exposed to a radiation dose of 30 Gy (KRN2) and 500 Gy (KRN7) whereupon the two different SAR protocols where tested. The ratio of the applied and calculated doses is called dose recovery ratio and would ideally be 1.00 .

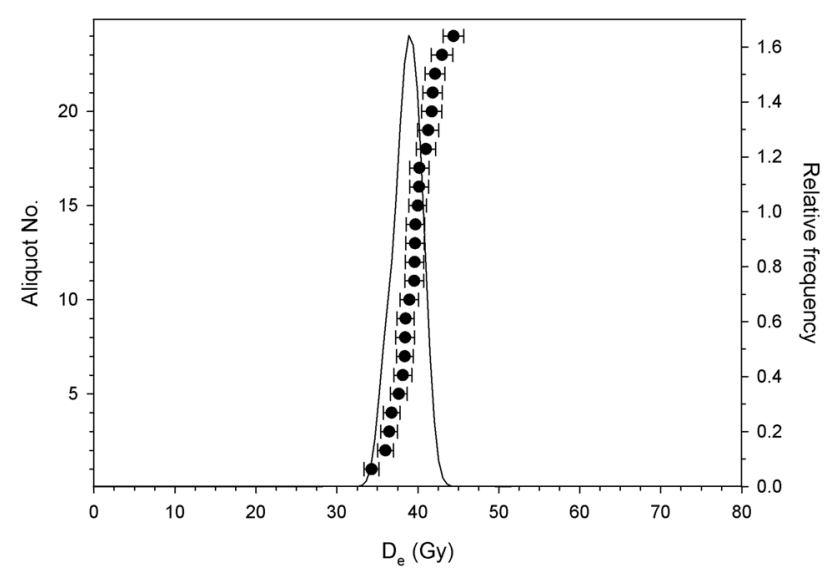

Fig. 4 Representative example of a $D_{\mathrm{e}}$ distribution (KRN2F, pIR-225)
As the different luminescence signals require different times to reset, a bleaching experiment was carried out for three of the samples (KRN1, 3, 9), in which a set of three aliquots each where exposed to the UV lamp for 1, 10, and $100 \mathrm{~h}$, after which the apparent residual dose was measured.

Finally, storage test for samples KRN2 and KRN7 were conducted on aliquots previously used for the dose recovery tests to estimate fading rates in two slightly different experiments (three aliquots each). In the first, the signal loss was monitored by repeating three cycles of delayed $L_{\mathrm{x}} / T_{\mathrm{x}}$ measurements with delay times of 100,1000 , and $10,000 \mathrm{~s}$. In the second experiment, again three cycles of delayed $L_{\mathrm{x}} / T_{\mathrm{x}}$ measurements were used but with delay times of 3600, 9000 , 18,000 , and $36,000 \mathrm{~s}$. The results of all experiments are discussed below.

Samples for dose rate measurements (ca. $200 \mathrm{~g}$ ) were dried and measured for the concentration of $\mathrm{K}$, Th and $\mathrm{U}$ by high-resolution gamma spectrometry (cf. Preusser and Kasper 2001). Alpha efficiency values were assumed at $0.07 \pm 0.02$ for feldspar, while for quartz the outer layer was removed during etching. Potassium content of feldspar was taken at $12.5 \pm 1.0 \%$ (Huntley and Baril 1997). Water content was assumed at $20 \pm 10 \%$ representing values close to saturation for this type of sediment (Saxton and Rawls 2006). The same value was also used by $\mathrm{Li}$ et al. (2018) for sediments of similar facies and setting from the Heidelberg Basin. Dose rates were calculated using ADELEv2017 (Degering and Degering 2020; add-ideas.de), taking into account longitude, latitude, and sample depth for cosmic dose rate (Prescott and Hutton 1994). The dosimetric data are compiled in Table 2.

\section{Results}

\section{Sedimentology, depositional environment, and provenance}

Figure 5 shows a schematic sketch of the core stratigraphy including the most prominent sedimentological characteristic. Accordingly, the sequence is sub-divided into five main units (A-E, from bottom to top).

Unit A (80.0-77.0 m depth) consists of compacted silt with a high carbonate content and an increasing amount of angular to sub-rounded clasts of grey carbonate, reddish sandstone, and quartz towards the top (diamict). The heavy mineral assemblage is characterised by epidote (30\%), garnet (24\%), and hornblende (15\%), representing the Rhenish Facies (Hagedorn and Boenigk 2008; Hoselmann 2008). Based on the lithological composition Unit A is interpreted to reflect gravitational soil creeping or mud flows, with two beds representing individual events. The heavy mineral assemblage implies that a substantial amount of sandy 


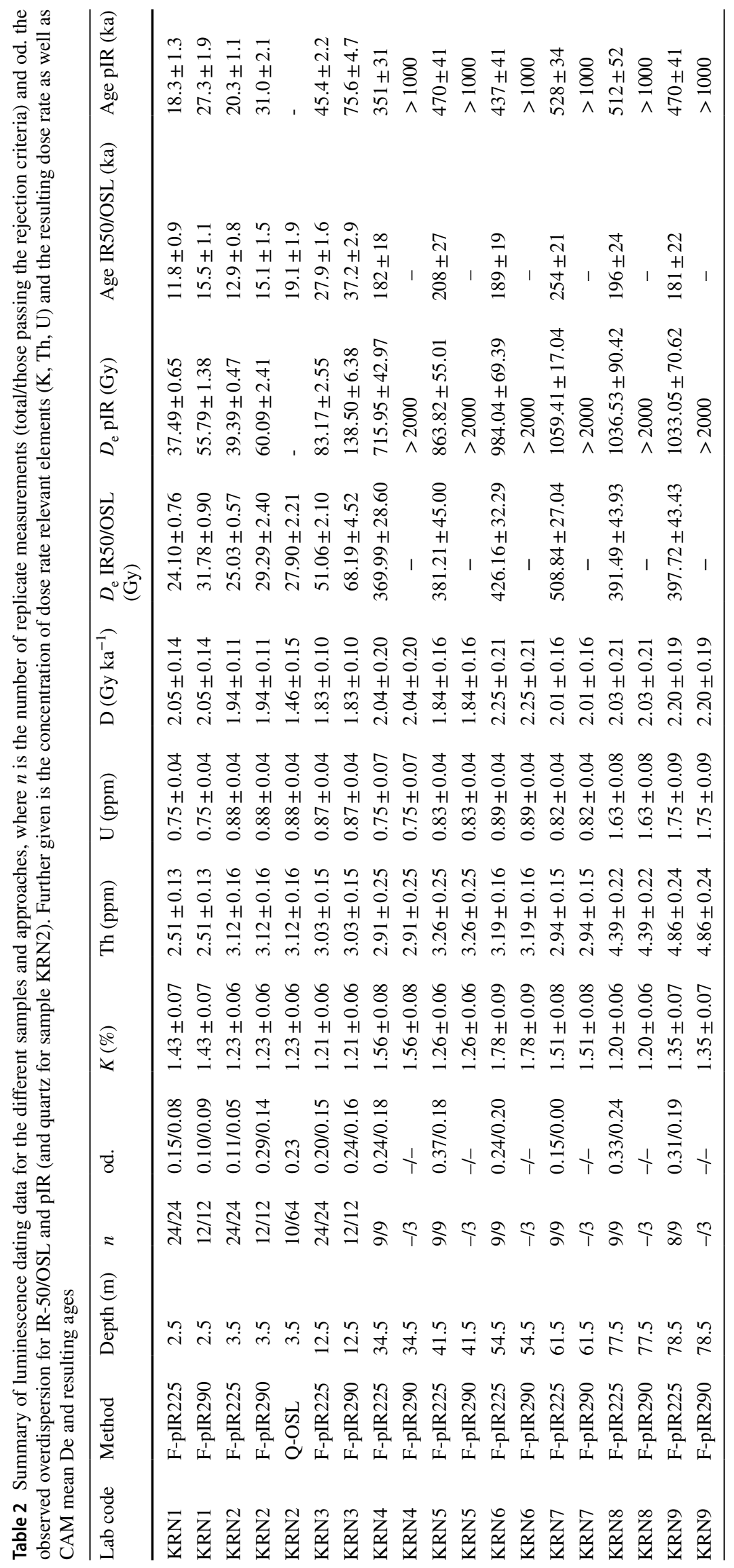


Fig. 5 Schematic sketch of the Kronau core with sediment classification according to grain size distribution, sorting, roundness, and heavy mineral assemblages. *Roundness: $S E$ sharp-edged, $A$ angular, $S A$ semi-angular, $S R$ semi-rounded, $R$ rounded, $W R$ well-rounded



deposits of the River Rhine were reworked by the slope processes. This is in line with the location of the site close to the eastern shoulder of the URG, where steep gradients could have enabled the development of solifluction sheets or mudflows due to freeze-thaw periods on the west-ward oriented slopes during times of colder climate. The high silt content could be explained by reworking of loess that partly covered the slope.

The overlying Unit B (77.0-51.5 m depth) is characterised by a monotonous series of moderately sorted, carbonate-bearing sand with fine- to coarse-grained, subangular to subrounded gravel. It contains isolated medium-grained gravel lenses and some large clasts of up to $5 \mathrm{~cm}$ diameter. From 77.0 to $60.0 \mathrm{~m}$ depth the sequence is partly diamictic and interpreted as the result of gravitational processes with local fluvial reworking. The deposits between 60.0 and $51.5 \mathrm{~m}$ depth are interpreted as being deposited in a fluvial environment with medium to low flow energy where bedload was deposited on bars, with rare high-energy flow events marked by the deposition of medium to coarse-grained gravel beds, where angular clasts indicate a proximal source. The composition of the gravel components enables the differentiation between a local (sandstones of the Buntsandstein and carbonatic mudstones) and an Alpine source, the latter represented by polymict breccias and conglomerates with veins, radiolarites, and weakly metamorphic quartzites. The heavy mineral spectrum is again of Rhine Facies but with a dominance of garnet (46\%) over epidote (18\%) and alterite $(10 \%)$, and less hornblende (7\%) for the samples taken at $62 \mathrm{~m}$. The sample taken at $54.5 \mathrm{~m}$ shows less garnet (22\%), but more hornblende (25\%), epidote (28\%), and zircone $(8 \%)$. However, moderate variability in heavy mineral composition is quite typical in deposits of the URG (Hagedorn and Boenigk 2008; Hoselmann 2008).

Unit $C$ (51.5-4.0 $\mathrm{m}$ depth) starts with a distinct change from rather well to poor sorting, together with an increase in the content of none-local clasts. The unit is characterised by shifts between well-sorted sandy deposits and poorlysorted, mainly massive gravel (Fig. 5). The latter usually show an erosive contact to the underlying unit but a gradual change in grain-size towards the top (fining-upwards). The most prominent gravel layers are found between 51.5 and $44 \mathrm{~m}$ (subunit C3) and 29-14 m (subunit C9). Two further gravel layers occur between 38 and $36 \mathrm{~m}$ (C5) and at ca. $33 \mathrm{~m}$ (C7). The petrographic composition of the pebbles indicates both a local (e.g., red sandstone) and Alpine (e.g., 
radiolarite) source. The sand fraction shows a high carbonate content and the Rhenish Facies in the heavy mineral assemblages that is quite similar for all five samples investigated ( $26 \pm 3 \%$ garnet, $20 \pm 5 \%$ epidote) with a rather high amount of hornblende $(23 \pm 2 \%)$.

The overall facies is interpreted as a fluvial environment where material was predominantly transported as bed-load and deposited as bars in braided channels. At the time of deposition, the massive gravel was deposited by a river system that was debris-overloaded while the fine-grained layers within the sequences represent a decrease in transport energy. This could be either caused by a climatically driven change in discharge or debris supply or a change towards a more distal depositional environment (e.g. floodplain) due to lateral migration of the main fluvial channel towards the graben centre in the West.

Unit $D(4.0-3.5 \mathrm{~m}$ depth) is a thin, homogenous, moderately to well-sorted, slightly silty sand layer with a high carbonate content and a yellowish-brown to slightly yellow colour and a sharp contact to Unit C. It contains a few angular to subangular medium-grained gravel components with up to $1 \mathrm{~cm}$ size. Lithologies of the clasts include milky quartz, calcareous tufa, and carbonatic mudstones. Based on the composition, the unit is interpreted as fluvially reworked loess. The composition of the clasts indicates that the source area is local, with calcareous tufa and carbonatic mudstones attributed to the Jurassic carbonates found on tectonic blocks close to the eastern graben boundary (e.g., close to the village of Bad Schönborn).

Unit E (3.5-0.0 m depth) represents moderately to wellsorted, medium sandy to fine gravelly fine sands. The coarser fractions have cubic shapes and are angular to subangular. Coarse gravel clasts are rare and have maximum grain sizes of less than $4 \mathrm{~cm}$. The matrix of this unit is free of carbonates. Clast lithologies include carbonatic mudstones, cherts, tufa, and milky quartz indicating that the majority of sediment was sourced locally. This unit is interpreted to represent deposition within a small-scale local stream system. The deposits may include a significant amount of reworked aeolian drift sand from local dune deposits.

\section{Luminescence dating}

In the dose recovery tests, we received a slight underestimation of IR-50 (recovery ratios between 0.81 and 0.90 for both samples and protocols), acceptable values for pIR-225 (0.98 and 1.13), and significantly overestimated values for pIR290 (>1.50). This implies potential problems with both the IR-50 and in particular the pIR-290 protocol. The results of the bleaching experiments (Fig. 6) show negligible residuals $\left(<1 \%\right.$ of natural $D_{\mathrm{e}}$ ) for IR-50 already after $1 \mathrm{~h}$ of light exposure and no further reduction with increased light exposure time. For pIR-225, after $1 \mathrm{~h}$ the highest residual is about



Fig. 6 Results of bleaching experiments for samples KRN1, KRN3, and KRN9 for IR-50, pIR-225, and pIR-290 (mean of three discs). The upper row shows the absolute values of residual dose (in Gray), the lower row as percentage of the natural mean $D_{\mathrm{e}}$

$7 \%$ of the natural and reduces to less than $2 \%$ after $100 \mathrm{~h}$ of light exposure. For pIR-290, residuals are always higher than for pIR-225 and are still above 5\% in the youngest sample (KRN1) after $100 \mathrm{~h}$ of bleaching.

The first set of storage test reveals consistent low fading rates (g-values) for both samples (KRN2 and KRN7), with average (unlogged CAM) values of $1.3 \pm 0.3 \% /$ decade for IR-50 and $0.1 \pm 0.5 \% /$ decade for pIR-225. These values were confirmed by the second set of experiments with an average of $1.6 \pm 0.5 \% / \mathrm{dec}$ ade for IR-50. For pIR-225, g-values of $1.3 \pm 0.6 \% /$ decade (KRN2) and $-1.3 \pm 1.5 \% /$ decade (KRN7) were calculated. From these experiments we expect little fading of the IR-50 signal, but no fading of pIR-225 (cf. Thiel et al. 2011).

The results of luminescence dating are summarised in Table 2. For the top three samples (KRN1-3) all individual $D_{\mathrm{e}}$ values plot within the near-to-linear part of the dose-response curves (similar to inset in Fig. 3b). The quartz OSL age for sample KRN2 (taken between 3.5 and $3.0 \mathrm{~m}$ ) is $19.1 \pm 1.9 \mathrm{ka}$. Feldspar ages for samples KRN2 
and KRN1 (the latter taken between 2.5 and $2.0 \mathrm{~m}$ from the same unit) are generally in the same order of magnitude but show some relevant differences between the three techniques applied. IR-50 ages derived from both the pIR-225 (KRN1: $11.8 \pm 0.9 \mathrm{ka} ; \mathrm{KRN} 2: 12.9 \pm 0.8 \mathrm{ka})$ and the pIR-290 protocol (KRN1: $15.5 \pm 1.1 \mathrm{ka}$; KRN2 $15.1 \pm 1.5 \mathrm{ka}$ ) are significantly younger than the quartz OSL age. While the pIR-225 ages are in excellent agreement with the quartz age (KRN1: $18.3 \pm 1.3$; KRN2: $20.3 \pm 1.1 \mathrm{ka}$ ), the pIR-290 ages are some $50 \%$ older (KRN1: $27.3 \pm 1.9$; KRN2: $31.0 \pm 2.1 \mathrm{ka})$. For sample KRN3 taken at $12.5 \mathrm{~m}$ depth, the IR-50 ages are $27.9 \pm 1.6 \mathrm{ka}$ (pIR-225 protocol) and 37.2 \pm 2.9 (pIR-290 protocol), while (slightly) higher ages have been calculated for pIR-225 $(45.4 \pm 2.2 \mathrm{ka})$ and pIR-290 $(75.6 \pm 4.7 \mathrm{ka})$.

The samples from the lower part of the core (KRN49) show significantly different ages for the individual approaches. The dose-response curves for IR-50 of both protocols are close-to-linear up to ca. $500 \mathrm{~Gy}$. Mean $\mathrm{D}_{\mathrm{e}}$ values for IR-50 (from the pIR-225 protocol) are around $400 \mathrm{~Gy}$, with corresponding ages of ca. $200 \mathrm{ka}$. For pIR-225, mean $\mathrm{D}_{\mathrm{e}}$ values of about $1000 \mathrm{~Gy}$ lie in the part of dose-response curves approaching but not reaching saturation and being below $2 D_{0}$ (inset in Fig. $3 \mathrm{c}$ ). The sample taken at $34.5 \mathrm{~m}$ (KRN4) has an pIR-225 age of $351 \pm 31 \mathrm{ka}$. The samples further below (KRN5-KRN9) have pIR-225 ages between $437 \pm 41 \mathrm{ka}$ and $528 \pm 34 \mathrm{ka}$, which all overlap within their uncertainties. For pIR-290, natural signals of samples KRN5-KRN9 are above the saturation level (inset Fig. 3d) that is reached at ca. $2000 \mathrm{~Gy}$.

\section{Discussion}

\section{Validity of luminescence chronology}

Among the different approaches applied, we consider the ages determined by pIR-225 as most reliable because, (1) the dose recovery tests yield the best results, (2) the spread of individual $D_{\mathrm{e}}$ values implies complete bleaching at the time of deposition, (3) no evidence for fading is observed in laboratory tests, and 4) the pIR age of sample KRN2 agrees very well with the quartz OSL age of the same sample. The much lower IR-50 ages throughout the core likely result from fading, as observed in storage tests, and possibly also from an increase in electron trapping probability (i.e. sensitivity) during the initial preheating, as indicated by the underestimation in the dose recovery tests (Wallinga et al. 2000). In contrast, electron trapping probability has apparently been significantly reduced during the initial preheating in the pIR-290 protocol, explaining the overestimation in the dose recovery tests and the fact that the natural pIR-290 signal is above the level of saturation (Fig. 3d). In contrast, the pIR225 signal is apparently not affected by this phenomenon.
The different behaviour of IR-50 and pIR in the same protocol implies that changes in electron trapping probability are trap-specific for the samples under consideration, which is in agreement with other studies (e.g. Zhang 2017; Qin et al. 2018). For the core Heidelberg Uni Nord (Fig. 1b), Li et al. (2018) also report a trend to overestimate dose recovery experiments for the pIR-290 signal. As a consequence, these authors abstained from applying this approach. The present study demonstrates that the decrease in sensitivity of the pIR-290 signal can indeed lead to a substantial overestimation of $D_{\mathrm{e}}$ and, hence, incorrect dating results.

Another interesting observation in comparison to the study by Li et al. (2018) is the fact that these authors observe significantly higher fading rates in their samples $(g>5 \%)$ decade compared to $g=1.3 \pm 0.3 \% /$ decade for IR-50 in this study; $g=$ ca. $2.1 \% /$ decade versus no fading for pIR-225 in this study). There appear three possibilities to explain this discrepancy. Firstly, although only $20 \mathrm{~km}$ further north, the core Heidelberg Uni Nord received its main sediment input from the River Neckar (Ellwanger et al. 2008), which may supply feldspar with different fading properties compared to Kronau. Secondly, the detection filter set (Schott BG-39 and HC 414/46 Interference filter) of the Lexsyg Smart cuts out UV emissions that are detected with the broad blue filter set (BG39 and Corning 7-59) used by Li et al. (2018). Krbetschek et al. (1997) argued that UV emissions show higher fading than blues emissions, which may explain the discrepancies between these two studies. However, this was not confirmed by experiments carried out by Thomsen et al. (2008). Thirdly, Schmidt et al. (2018) have recently shown that the heating characteristics in Lexsyg (as used here) and Ris $\varnothing$ (as used by Li et al. 2018) OSL readers are crucially different. We confirm by own observations that $225^{\circ} \mathrm{C}$ in the Lexsyg Smart correspond to higher temperatures $\left(20-30{ }^{\circ} \mathrm{C}\right)$ in a Ris $\varnothing$ machine. As the measurements presented here were carried out before the publication of the article by Schmidt et al. (2018), no adjustment of measurement parameters was considered. Hence, it is possible if not likely that the signal sampled here shows less fading due to the higher applied stimulation temperature. For future studies, this suggests that it might be interesting to systematically explore if pIR stimulation at $250{ }^{\circ} \mathrm{C}$ (in a Ris $\varnothing$ reader) might be the more appropriate option for dating. This approach may combine low fading with a still quite rapid signal resetting by daylight, as demonstrated by the bleaching experiments, and no change in electron trapping probability during preheat. Indeed, Faershtein et al. (2020) preferred the pIR-250 approach over pIR-225 and pIR-290, though some minor fading was observed in their samples $(g<1.6 \%$ per decade). Concordantly, Zhang and $\mathrm{Li}$ (2020) expect the highest potential to date old samples (up to $1000 \mathrm{~Gy}$ and possible beyond) by using pIR-250, but in connection with the application of a multiple-elevated-temperature protocol. 
In summary, it appears reasonable to expect that the pIR225 ages presented here represent the real time of sediment deposition, with justifies their use for the chronostratigraphic interpretation. While the samples from the lower part of the core are in the critical upper age range of the method (i.e. in the upper part of the dose-response curve), the ages are considered likely reliable since the $\mathrm{D}_{\mathrm{e}}$ values are still below $2 \mathrm{D}_{0}$ (=86\% saturation; cf. Wintle and Murray 2006). The fact that ages do not increase below $40 \mathrm{~m}$ could be interpreted to represent reaching the equilibrium between signal gain (from the interaction of ionising radiation with the minerals) and signal loss (from fading; cf. Li and Li 2008). Indeed, a minor effect of fading that will be difficult to be detected in storage tests and cannot entirely be excluded from the present data set. On the other hand, the lack of age increase with depth could also represent a higher accumulation rate, possibly in connection with a period of local subsidence. To answer the question regarding the upper dating limit of the applied pIR-225 dating approach in this region, it is necessary to investigate cores reaching further back in time and, ideally, with an age control given by, for example, palynoand magneto-stratigraphy. However, as the lower $30 \mathrm{~m}$ of the investigated core are not highly relevant for the correlations proposed further below, solving the question of the remaining uncertainty regarding the upper dating limit of pIR-225 is not essential for the focus of the present study.

\section{Timing and nature of fluvial dynamics in the URG}

The lowest part of the Kronau sequence likely comprises slope toe deposits (Unit A) and fluvial sediments attributed to a local stream (Unit B) but with substantial mixing with material of Alpine origin. The result of pIR-225 dating of this part of the sequence gave statistically consistent ages of $470 \pm 41 \mathrm{ka}(\mathrm{KRN} 9), 512 \pm 52 \mathrm{ka}$ (KRN8), and $528 \pm 33 \mathrm{ka}$ (KRN7), representing a mean (CAM) age of $508 \pm 23 \mathrm{ka}$. The ages place this phase of aggradation at the boundary between Marine Isotope Stage (MIS) 14 and 13 (524 ka; Fig. 7). In the continental stratigraphy, this represents the upper part of the Cromerian Complex, a period comprising a total of four individual interglacials that are separated by cooler phases. The age assigned to the Cromerian is ca. $800-450 \mathrm{ka}$ and includes the B/M boundary in its lower part (Zagwijn 1985, 1992).

The first prominent coarse gravel layer on top of Unit B is bracketed by two pIR-225 ages of $437 \pm 41 \mathrm{ka}$ (KRN6) and $470 \pm 41 \mathrm{ka}(\mathrm{KRN} 5)$, with a mean (CAM) age of $454 \pm 29 \mathrm{ka}$. This age corresponds to the global glaciation maximum of MIS 12 (478-424 ka). The mean (CAM) of three pIR-225 ages reported by Li et al. (2018) for the uppermost part of the Ludwigshafen Formation in the Heidelberg Uni Nord core is $431 \pm 26 \mathrm{ka}$, with the overlying basal part of the Mannheim Formation represented by a prominent coarse gravel layer. Similar changes in deposition style, i.e. a change from sandy to coarser sedimentation, are observed in the cores from Ludwigshafen and Viernheim at a similar stratigraphic position (Hoselmann 2008; Weidenfeller and Knipping 2008; Lauer et al. 2010, 2011; Menzies and Ellwanger 2012, 2015; Gabriel et al. 2013).

In contrast to the above, previous publications have placed the boundary between the Ludwigshafen and Mannheim Formation after the Holsteinian, i.e. after ca. $374 \mathrm{ka}$. This is some 50-80 ka later than suggested by the dating results presented here and by Li et al. (2018). The assignment of the age of the boundary is based on the occurrence of interglacial pollen assemblages investigated in a number of cores from the Heidelberg Basin (Hahne et al. 2012). However, it has to be noted that most of the investigated Middle Pleistocene interglacial sequences are fragmentary, poorly preserved, and partly comprise a few samples only. Furthermore, no detailed documentation of the data (pollen diagrams) has been provided for most of the investigated cores. According to Hahne et al. (2012), the Holsteinian in the URG is characterised by a dominance of Abies (fir), in combination with a low occurrence of Corylus (hazel), low abundance of mixed-oak taxa (mainly Quercus), and low values of Buxus (box tree) during the early phase of the interglacial. The expansion of Carpinus (hornbeam) is seen as characteristic, together with a later spread of Fagus (beech) and Pterocarya (wingnut). For the latter, Hahne et al. (2012) state that the percentage of pollen is highly variable, even for nearby sites (between 1 and 30\%). However, the reference site for this characterisation of the Holsteinian (Forster Busch) is located in the Lower Rhine Embayment, some $300 \mathrm{~km} \mathrm{NW}$ of the Heidelberg Basin. Hahne et al. (2012) highlight that no complete sequence of the Holsteinian is known from the URG and that fragmentary sequences could erroneously be correlated with the Cromerian. However, an interglacial pollen assemblage from the borehole Käfertal near Mannheim (Fig. 1b) is correlated to the Holsteinian despite the fact that the phase of Abies dominance is represented by one sample only and the essential phase with Carpinus-Fagus-Pterocarya is not clearly represented. In fact, Middle Pleistocene pollen stratigraphy is generally far from being straightforward, as detailed in a number of publications (e.g. de Beaulieu et al. 2001; Urban et al. 2011; Bittmann 2012; Stephan 2014). For the URG, Hahne et al. (2012) assign only two interglacials to the Cromerian Complex although it comprises four such phases (Zagwijn 1985, 1992). A possible correlation of pollen assemblages assigned to the Holsteinian with the Mannheim-Interglacial, as identified in the borehole Ludwigshafen-Parkinsel P34 (26.56-29.05 m) and assigned to the late Cromerian by Knipping (2008) and Weidenfeller and Knipping (2008), is not discussed by Hahne et al. (2012). In summary, the interpretation by Hahne et al. (2012) that interglacial pollen 


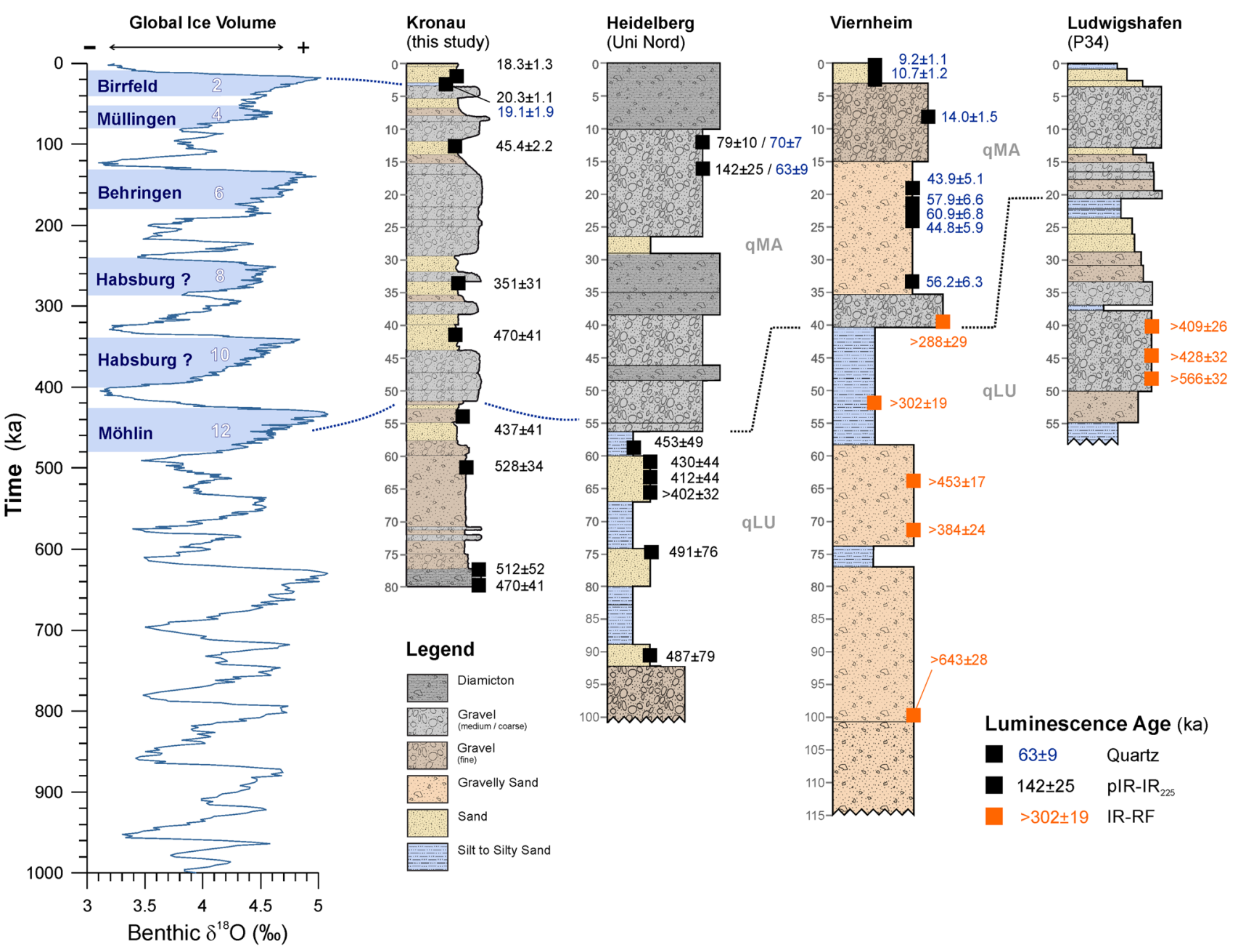

Fig. 7 Suggested correlation of fluvial sediment aggradation in the URG based on luminescence dating, in combination with changes in depositional style with the glaciation history of northern Switzerland (Preusser et al. 2011), and the marine isotope stack as a measure of global ice volume and climatic conditions (Lisicki and Raymo 2005).

assemblages in the upper part of the Ludwigshafen Formation must be of Holsteinian age is rather weak. A correlation with the Cromerian appears, at least, as likely, and would be in perfect agreement with the results of luminescence dating presented here and by $\mathrm{Li}$ et al. (2018). Interestingly, Menzies and Ellwanger (2015) also suggest to tentatively correlate the Mannheim Formation and assign the topic of the Ludwigshafen Formation to the Cromerian.

Considering the overall environmental context, it appears likely that the change towards coarse deposition in the southern and central URG is related to large-scale climatic controls. The most likely scenarios would an expansion of glaciers far into the foreland. Otherwise, it is difficult to explain the presence of massive coarse and poorly-sorted gravel some $300 \mathrm{~km}$ away from the margin of the Alps as the presence of lakes in the Alpine foreland after major
Logging data and luminescence ages were derived from various sources (Ellwanger et al. 2008; Hoselmann et al. 2008; Weidenfeller and Knipping 2008; Ellwanger and Wieland-Schuster 2012; Gabriel et al. 2013; Lauer et al. 2010, 2011; Li et al. 2018)

glaciations will have buffered the transport of coarse material towards the URG. In contrast to the coarse gravel layers, the well-sorted sandy and gravelly sediments are interpreted to reflect re-working of older deposits (indicated by Alpine heavy mineral assemblages). This occurred possibly during periods of less severe climate (interstadials to stadials) without the presence of Alpine glaciers in the foreland.

According to the results of pIR dating, this change in depositional style at Kronau dates to a mean age of $454 \pm 29 \mathrm{ka}$ (mean of KRN5 and KRN6) and is thus contemporaneous with the age of the Hosskirchian Glaciation in the Lake Constance area (Ellwanger et al. 2011; Hahne et al. 2012). The Hosskirchian just predates the Holsteinian (424-374 ka) and represents the first phase with a formation of overdeepened structures in the respective region, which implies major erosion and increased debris supply to the drainage system 
(cf. Preusser et al. 2010). In Switzerland, the Thalgut site (south of Bern, close to the border of the Alps) provides the only robust evidence for a glaciation occurring directly prior to the Holsteinian (Schlüchter 1989a, b; Welten 1988). Preusser et al. (2011) speculate that this glaciation corresponds to the Möhlin Glaciation, the most extensive ice advance documented in northern Switzerland (Graf 2009). Accordingly, Gaar and Preusser (2017) conclude that the Möhlin Glaciation has to pre-date MIS 6. Considering the presence of glacial deposits below Holsteinian sediments at Thalgut, in combination with the expected age of the Hosskirchian, it appears most reasonable to attribute the Möhlin Glaciation to MIS 12 (478-424 ka). The maximum ice extent of this glaciation was in the Rhine Valley some $20 \mathrm{~km}$ east of Basel, where the river changes its direction and flows into the URG. As a consequence, it is assumed that the onset of poorly-sorted but moderately rounded gravel aggradation at Kronau represents semi-distal meltwater deposits that were deposited as a result of the Möhlin Glaciation.

At Kronau, two rather thin gravel layers occur above the first prominent gravel layer, bracketing a sandy horizon dated to $351 \pm 26 \mathrm{ka}$. While the available data is limited, it is interesting to note that this part of the sequence would chronologically correlate with MIS 10-8 (374-243 ka), a period with little evidence for widespread glaciation but presumably cold conditions (e.g., Reille and de Beaulieu 1995). In Switzerland, one of these phases might be represented by the Habsburg Glaciation (Graf 2009) that is expected to be younger than Möhlin (MIS12) but older than Beringen (MIS 6). At Meikirch, located in the Aare Valley north of Bern, glacial deposits are overlain by lacustrine sediments containing pollen assemblages that imply a correlation with MIS 7, confirmed by luminescence dating (Preusser et al. 2005). The basal glacial deposits at Meikirch could well be assigned to the Habsburg Glaciation that had an extent similar to the last glaciation maximum (Keller and Krayss 2010; Preusser et al. 2011).

The most prominent feature of the Kronau sequence is the massive and thick aggradation of coarse and poorly sorted gravel between 30 and $15 \mathrm{~m}$. Unfortunately, it was not possible to take samples from the sand below this part due to core preservation issues, which leaves uncertainty with regard to the exact timing of the onset of this depositional interval. The end of deposition is constrained by a pIR-225 age of $45.4 \pm 2.3 \mathrm{ka}$, corresponding to the middle part of MIS 3 and moderately cold climatic conditions in Switzerland (cf. Heiri et al. 2014). Considering the available age information two pronounced cold phases with associated glaciations remain as potential candidates, namely MIS 6 and 4. The former is known as the second most extensive glaciation in Switzerland (Beringen; Graf 2009) and chronologically constrained by several luminescence ages (e.g., Dehnert et al.
2010; Preusser et al. 2011; Lowick et al. 2015). For northern Switzerland, there is also evidence for a major glaciation during MIS 4 that apparently reached almost the extent of MIS 2 (Preusser et al. 2007; Gaar et al. 2019). Interestingly, aggradation during MIS 4 appears to be quite prominent in the cores from Viernheim (Lauer et al. 2010) and Heidelberg (Li et al. 2018).

The final phase of coarse-grained deposition at Kronau is bracketed by an age of $45.4 \pm 2.3 \mathrm{ka}$ determined for sand from below and three ages of $20.3 \pm 0.8 \mathrm{ka}$ (pIR), $19.1 \pm 1.7 \mathrm{ka}(\mathrm{OSL})$, and $18.3 \pm 1.0 \mathrm{ka}(\mathrm{pIR})$ for sand from above upper gravel layer. This corresponds to the last glaciation of the Swiss Alpine Foreland (Birrfeld Glaciation; Graf 2009 that occurred between ca. 30-20 ka ago (IvyOchs et al. 2008; Gaar et al. 2019). In agreement with data from the northern URG (Dambeck 2005; Erkens et al. 2009), aggradation of coarse material stopped by the latest ca. $20 \mathrm{ka}$. The top part of the Kronau sequence likely reflects the reworking of aeolian deposits by local streams.

\section{Conclusions}

The sedimentological investigations in combination with luminescence dating of the Kronau 'Reimold' core provide new insights into the aggradation history of the URG. In agreement with evidence from the Heidelberg Basin Drilling Project it appears that the deposition of coarse gravel layers can be correlated with the expected age of glaciations of the Swiss Alpine Foreland. The first major pulse of aggradation recorded at Kronau occurred during the Möhlin Glaciation, which corresponds to MIS 12 (478-424 ka). In the URG, this is represented in the shift from the overall more fine-grained Ludwigshafen to the generally coarser Mannheim Formation. However, this does not represent the first wide-spread glaciation of the foreland of the Swiss Alps, as evidence of up to eight glaciations has been discussed for the Early Pleistocene (summarised by Preusser et al. 2011). Indeed, coarse deposition has been observed in the lower part of the Heidelberg borehole, with an age $>800$ ka based on pollen stratigraphy (Gabriel et al. 2013) and magnetostratigraphy (Scheidt et al. 2015), and this may represent the Early Pleistocene 'Deckenschotter Glaciations' of northern Switzerland. Two minor phases of gravel accumulation at Kronau may correlate with MIS 10 (374-337 ka) and MIS 8 (300-243 ka), with the Habsburg Glaciation being a candidate for correlation with one of these phases. However, for this phase, no direct dating results are available so far. Probably due to the lack of suitable sand layers, there is yet no direct evidence for deposition in the URG during the Beringen Glaciation, which is well documented and dated in Switzerland (and elsewhere, Rissian), and correlates to MIS 6 (191-130 ka). 
Interestingly, there is evidence in the URG for prominent accumulation during MIS 4 (71-57 ka), a period for which only initial evidence of a widespread glaciation is available from the Alps. The last glaciation (Birrfeld) that occurred during MIS 2 (29-14 ka) is also represented in deposits of the URG. Altogether, the Middle to Late Pleistocene aggradation history of the URG is much more complex compared than suggested by the simple scheme developed by Bartz et al. (1982) with major implications for the architecture of aquifers and aquitards. For example, the Mannheim Formation will possibly comprise up to six phases of gravel depositions alternating with periods of erosion and deposition of fine-grained material. However, these will likely not have been completely preserved in most part of the graben.

While the above reconstruction appears rather plausible, it should be kept in mind that it is based on a limited number of age determinations and certain assumptions, where direct dating is missing (i.e., to prove deposition during MIS 6). It is recommended to apply the combination of sedimentology, provenance studies (heavy minerals and clast petrography), and luminescence dating to cores from the southern URG. There, the signal form the Alps might be even more clearly visible. The applied pIR-225 approach appears to provide reliable ages of up to at least $500 \mathrm{ka}$ but its age range could be further tested by sampling sediment from just above and below the Brunhes/Matuyama magnetic boundary $(776 \pm 14 \mathrm{ka})$. In fact, there are several parts in the cores from the Heidelberg Basin for which applying the pIR approach used here appears reasonable. Furthermore, very recently the application of luminescence to date large clasts (pebbles and cobbles) has been proven to have a high potential to directly date coarse sediment layers that are not suitable for conventional luminescence approaches (e.g., Jenkins et al. 2018). Using this approach, it should be likely possible to establish reliable chronologies for both the Alpine glaciations and the fluvial aggradation in the URG. A further topic to be addressed would be aiming at identifying phases of gravel aggradation and correlating these with the so far poorly constrained glaciation Early Pleistocene glaciations in northern Switzerland. As dating such deposits is almost likely beyond the range of luminescence dating, this could be tested applying cosmogenic nuclide dating.

Acknowledgements Gamma spectrometric measurements were carried out by Sönke Szidat at the University of Bern. The contributions by HAK and DM to this study were carried out while both were funded through grants by the Swiss National Cooperative for the Disposal of Radioactive Waste (NAGRA). We thank Frank Kiesewetter for providing us access to the core and hospitality. Michael Weidenfeller generously made his original logging protocol of the Ludwigshafen P34 core available. Philipp Stojakowits is thanked for his feedback regarding the interpretation of pollen data. We especially thank Ulrike Wieland-Schuster for her critical comments on several earlier drafts of the manuscript, in particular with regard to the regional Quaternary geology. The manuscript benefited from constructive reviews by Giovanni Monegato and an anonymous reviewer.

Funding Open Access funding enabled and organized by Projekt DEAL.

Open Access This article is licensed under a Creative Commons Attribution 4.0 International License, which permits use, sharing, adaptation, distribution and reproduction in any medium or format, as long as you give appropriate credit to the original author(s) and the source, provide a link to the Creative Commons licence, and indicate if changes were made. The images or other third party material in this article are included in the article's Creative Commons licence, unless indicated otherwise in a credit line to the material. If material is not included in the article's Creative Commons licence and your intended use is not permitted by statutory regulation or exceeds the permitted use, you will need to obtain permission directly from the copyright holder. To view a copy of this licence, visit http://creativecommons.org/licenses/by/4.0/.

\section{References}

Ampel L, Wohlfarth B, Risberg J, Veres D, Leng MJ, Kaislahti Tillman P (2010) Diatom assemblage dynamics during abrupt climate change: The response of lacustrine diatoms to DansgaardOeschger cycles during the last glacial period. J Paleolimnol 44:397-404

Bartz J, Von der Brelie G, Maus H (1982) Quartär und Jungtertiär II im Oberrheingraben im Großraum Karlsruhe. Geol Jahrb A63:3-237

Bittmann F (2012) Die Schöninger Pollendiagramme und ihre Stellung im mitteleuropäischen Mittelpleistozän. In: Behre KE (ed.). Die chronologische Einordnung der paläolithischen Fundstellen von Schöningen, Verlag des Römisch-Germanischen Zentralmuseums Mainz. pp 97-112

Boenigk W (1983) Schwermineralanalyse. Enke, Stuttgart

Boenigk W (1987) Petrographische untersuchungen jungtertiärer und quartärer sedimente am linken oberrhein. Jahrb Mitt Oberrhein Geol Ver NF 69:357-394

Boenigk W, Frechen M (2006) The Pliocene and quaternary fluvial archives of the rhine system. Quat Sci Rev 25:550-574

Buylaert JP, Murray AS, Thomsen KJ, Jain M (2009) Testing the potential of an elevated temperature IRSL signal from K-feldspar. Rad Meas 44:560-565

Chen YW, Li SH, Li B (2013) Residual doses and sensitivity change of post IR IRSL signals from potassium feldspar under different bleaching conditions. Geochronometria 40:229-238

Dambeck R (2005) Beiträge zur spät- und postglazialen Fluss- und Landschaftsgeschichte im nördlichen Oberrheingraben. Ph.D. thesis Johann Wolfgang Goethe Universität Frankfurt am Main. pp 245

de Beaulieu JL, Andrieu-Ponel V, Reille M, Grüger E, Tzedakis C, Svoboda H (2001) An attempt at correlation between the Velay pollen sequence and the Middle Pleistocene stratigraphy from central Europe. Quat Sci Rev 20:1593-1602

Degering D, Degering A (2020) Change is the only constant-timedependent dose rates in luminescence dating. Quat Geochron 58:101074

Dehnert A, Preusser F, Kramers JD, Akçar N, Kubik PW, Reber R, Schlüchter C (2010) A multi-dating approach applied to proglacial sediments attributed to the Most Extensive Glaciation of the Swiss Alps. Boreas 39:620-632 
Doppler G, Kroemer E, Rögner K, Wallner J, Jerz H, Grottenthaler W (2011) Quaternary Stratigraphy of Southern Bavaria. E\&G Quat Sci J 60:329-365

Duller GAT (2003) Distinguishing quartz and feldspar in single grain luminescence measurements. Rad Meas 37:161-165

Ehlers J, Gibbard PL (2007) The extent and chronology of Cenozoic Global Glaciation. Quat Int 165(165):6-20

Ellwanger D, Lämmermann-Barthel J, Neeb I (2003) Eine Landschaftsübergreifende Lockergesteinsgliederung vom Alpenrand bis zum Oberrhein. GeoArchaeoRhein 4:81-125

Ellwanger D, Gabriel G, Simon T, Wielandt-Schuster U, Greiling RO, Hagedorn EM, Hahne J, Heinz J (2008) Long sequence of Quaternary rocks in the Heidelberg Basin depocentre. E\&G Quat Sci J 57:316-337

Ellwanger D, Wielandt-Schuster U, Franz M, Simon T (2011) The Quaternary of the southwest German Alpine Foreland (Bodensee-Oberschwaben, Baden-Württemberg, Southwest Germany). E\&G Quat Sci J 60:306-328

Ellwanger D, Franz M, Wiedlandt-Schuster U (2012) Zur Einführung: Heidelberger Becken, Oberschwaben-Oberrhein, Geosystem Rhein. LGRB Info 26:7-24

Erkens G, Dambeck R, Volleberg KP, Bouman MTIJ, Bos JAA, Cohen KM, Wallinga J, Hoek WZ (2009) Fluvial terrace formation in the northern Upper Rhine Graben during the last 20000 years as a result of allogenic controls and autogenic evolution. Geomorphology 103:476-495

Faershtein G, Porat N, Matmon A (2020) Extended-range luminescence dating of quartz and alkali feldspar from aeolian sediments in the eastern Mediterranean. Geochronology 2:101-118

Gaar D, Preusser F (2017) Age of the most extensive glaciation of northern switzerland: evidence from the scientific drilling at möhliner feld. E\&G Quat Sci J 66:ER1-5

Gaar D, Graf HR, Preusser F (2019) New chronological constraints on the timing of Late Pleistocene glacier advances in Northern Switzerland. E\&G Quat Sci J 68:53-73

Gabriel G, Ellwanger D, Hoselmann C, Weidenfeller M (2008) The Heidelberg basin drilling project. E\&G Quat Sci J 57:253-432

Gabriel G, Ellwanger D, Hoselmann C, Weidenfeller M, WielandtSchuster U, The Heidelberg Basin Project Team (2013) The Heidelberg Basin, Upper Rhine Graben (Germany): a unique archive of Quaternary sediments in Central Europe. Quat Int 292:43-58

Galbraith RF, Roberts RG, Laslett GM, Yoshida H, Olley JM (1999) Optical dating of single grains of quartz from Jinmium rock shelter, northern Australia. Part I: experimental design and statistical models. Archaeometry 41:339-364

Garzanti E, Vezzoli G, Andò S (2011) Paleogeographic and paleodrainage changes during Pleistocene glaciations (Po Plain, Northern Italy). Earth Sci Rev 105:25-48

GeORG-Projektteam (2013) Geopotenziale des tieferen Untergrundes im Oberrheingraben, Fachlich-Technischer Abschlussbericht des INTERREG Projekts GeORG, Teil 1. LGRB Info 28:103 pp

Ghaleb B, Falguères C, Carlut J, Pozzi JP, Mahieux G, Boudad L, Rousseau L (2019) Timing of the Brunhes-Matuyama transition constrained by U-series disequilibrium. Sci Rep 9:6039

Giamboni M, Ustaszewski K, Schmid SM, Schuhmacher ME, Wetzel A (2004) Plio-Pleistocene transpressional reactivation of Paleozoic and Paleogene structures in the Rhine-Bresse transformal zone (northern Switzerland and eastern France). Int J Earth Sci 93:207-223

Graf HR (2009) Mittel- und Spätpleistozän in der zentralen Nordschweiz. Beiträge zur geologischen Karte der Schweiz NF. 168:198 $\mathrm{pp}$

Hagedorn EM, Boenigk W (2008) The Pliocene and Quaternary sedimentary and fluvial history in the Upper Rhine Graben based on heavy mineral analyses. Neth J Geosci 87:21-32
Hahne J, Ellwanger D, Franz M, Stritzke R, Wielandt-Schuster U (2012) Pollenanalytische Untersuchungsergebnisse aus dem baden-württembergischen Rheinsystem Oberrheingraben, Hochrhein, Oberschwaben-eine Zusammenfassung des aktuellen Kenntnisstandes. LGRB Info 26:119-154

Heiri O, Koinig KA, Spötl C, Barrett S, Brauer A, Drescher-Schneider R, Gaar D, Ivy-Ochs S, Kerschner H, Luetscher M, Moran A, Nicolussi K, Preusser F, Schmidt R, Schoeneich P, Schwörer C, Sprafke T, Terhorst B, Tinner W (2014) Palaeoclimate records 60-8 ka in the Austrian and Swiss Alps and their forelands. Quat Sci Rev 106:186-205

Hinderer M (2001) Late Quaternary denudation of the Alps, valley and lake fillings and modern river loads. Geodin Acta 14:231-263

Hoselmann C (2008) The Pliocene and Pleistocene fluvial evolution in the northern Upper Rhine Graben based on results of the research borehole at Viernheim (Hessen, Germany). E\&G Quat Sci J 57:286-315

Huggenberger P, Regli C (2006) A sedimentological model to characterize braided river deposits for hydrogeological application. Braided Rivers. IN: Sambrook Smith GH, Best JL, Bristow CS, Petts GE (Eds.). Int Assoc Sediment 36:51-74

Huntley D, Baril M (1997) The K content of the K-feldspars being measured in optical and thermoluminescence dating. Ancient TL 15:11-13

Hüttner R (1991) Bau und Entwicklung des Oberrheingrabens-Ein Überblick mit historischer Rückschau. Geol Jahrb E48:17-42

Illies H (1974) Intra-Plattentektonik in Mitteleuropa und der Rheingraben. Oberrh Geol Abh 23:1-24

Illies H (1977) Ancient and recent rifting in the Rhinegraben. Geol Mijnbouw 56:329-350

Ivy-Ochs S, Kerschner H, Reuther A, Preusser F, Heine K, Kubik PW, Maisch M, Schlüchter C (2008) Chronology of the last glacial cycle in the European Alps. J Quat Sci 23:559-573

Jenkins GTH, Duller GAT, Roberts HM, Chiverrell RC, Glasser NF (2018) A new approach for luminescence dating glaciofluvial deposits-High precision optical dating of cobbles. Quat Sci Rev 192:263-273

Jost-Stauffer MA, Coope GR, Schlüchter C (2001) A coleopteran fauna from the middle Würm (Weichselian) of Switzerland and its bearing on palaeogeography, palaeoclimate and palaeoecology. J Quat Sci 16:257-268

Keller O, Krayss E (2010) Mittel- und spätpleistozäne Stratigraphie und Morphogenese in Schlüsselregionen der Nordschweiz. E\&G Quat Sci J 59:88-119

Kemna HA (2008) A revised stratigraphy for the Pliocene and Lower Pleistocene deposits of the Lower Rhine Embayment. Neth J Geosci 87:91-105

King GE, Burow C, Roberts HM, Pearce NJG (2018) Age determination using feldspar: Evaluating fading-correction model performance. Rad Meas 119:58-73

Knipping M (2008) Early and Middle Pleistocene pollen assemblages of deepcore drillings in the northern Upper Rhine Graben, Germany. Neth J Geosci 87:51-65

Kock S, Kramers JD, Preusser F, Wetzel A (2009) Dating of Late Pleistocene deposits of River Rhine using Uranium series and luminescence methods: potential and limitations. Quat Geochron 4:363-373

Krbetschek MR, Götze J, Dietrich A, Trautmann AT (1997) Spectral information from minerals relevant for luminescence dating. Rad Meas 27:695-748

Laubscher H (2001) Plate interactions at the southern end of the Rhine graben. Tectonophysics 343:1-19

Lauer T, Weiss M (2018) Timing of the Saalian- and Elsterian glacial cycles and the implications for Middle-Pleistocene hominin presence in central Europe. Sci Rep 8:5111 
Lauer T, Frechen M, Hoselmann C, Tsukamoto S (2010) Fluvial aggradation phases in the Upper Rhine Graben-new insights by quartz OSL dating. Proc Geol Assoc 121:154-161

Lauer T, Krbetschek M, Frechen M, Tsukamoto S, Hoselmann C, Weidenfeller M (2011) Infrared radiofluorescence (IR-RF) dating of Middle Pleistocene fluvial archives of the Heidelberg Basin (Southwest Germany). Geochronometria 38:23-33

Leeder MR, Harris T, Kirkby MJ (1998) Sediment supply and climate change: implications for basin stratigraphy. Basin Res 10:7-18

LGRB = Landesamt für Geologie, Rohstoffe und Bergbau (2012) Die Forschungsbohrung Heidelberg und Beiträge zum Quartär in Baden-Württemberg. LGRB-Inf 26:1-216

Li B, Li SH (2008) Investigations of the dose-dependent anomalous fading rate of feldspar from sediments. J Phys D-Appl Phys 41:225502

Li B, Jacobs Y, Roberts RG, Li SH (2014) Review and assessment of the potential of post-IR IRSL dating methods to circumvent the problem of anomalous fading in feldspar luminescence. Geochronometria 41:178-201

Li Y, Tsukamoto S, FrechenGabriel MG (2018) Timing of fluvial sedimentation in the Upper Rhine Graben since the Middle Pleistocene: constraints from quartz and feldspar luminescence dating. Boreas 47:256-270

Lisiecki L, Raymo ME (2005) A Pliocene-Pleistocene stack of 57 globally distributed benthic ${ }^{18} \mathrm{O}$ records. Paleoceanography 20:PA1003

LithoLex (2011) Online database https://litholex.bgr.de

Lowick S, Buechi M, Gaar D, Graf HR, Preusser F (2015) Luminescence dating of Middle Pleistocene proglacial deposits from northern Switzerland: methodological aspects and stratigraphical conclusions. Boreas 44:459-482

Menzies J, Ellwanger D (2012) Micromorphology of the Mannheim Formation taken from the UniNord Core, Heidelberg Basin Depocentre, Upper Rhine Graben. LGRB Info 26:87-106

Menzies J, Ellwanger D (2015) Climate and paleo-environmental change within the Mannheim Formation near Heidelberg, Upper Rhine Valley, Germany: a case study based upon microsedimentological analyses. Quat Int 386:137-147

Murray AS, Wintle AG (2000) Luminescence dating of quartz using an improved single-aliquot regenerative-dose protocol. Rad Meas 32:57-73

Nádor A, Lantos M, Tóth-Makk A, Thamó-Bozsó E (2003) Milankovitch-scale multi-proxy records from fluvial sediments of the last 2.6 Ma, Pannonian Basin, Hungary. Quat Sci Rev 22:2157-2175

Penck A, Brückner E (1901-09) Die Alpen im Eiszeitalter. Tauchnitz, Leipzig.

Peters G, van Balen RT (2007) Tectonic geomorphology of the northern Upper Rhine Graben, Germany. Glob Planet Change 58:310-334

Petit C, Campy M, Chaline J, Bonvalot J (1996) Major paleohydrographic changes in Alpine foreland during the Plio-Pleistocene. Boreas 25:131-143

Prescott JR, Hutton JT (1994) Cosmic ray contributions to dose rates for luminescence and ESR dating: large depths and long-term time variations. Rad Meas 23:497-500

Preusser F (2008) Characterisation and evolution of the River Rhine system. Neth J Geosci 87:7-19

Preusser F, Kasper HU (2001) Comparison of dose rate determination using high-resolution gamma spectrometry and inductively coupled plasma-mass spectrometry. Anc TL 19:19-23

Preusser F, Drescher-Schneider R, Fiebig M, Schlüchter C (2005) Reinterpretation of the Meikirch pollen record, Swiss Alpine Foreland, and implications for Middle Pleistocene chronostratigraphy. J Quat Sci 20:607-620

Preusser F, Blei A, Graf HR, Schlüchter C (2007) Luminescence dating of Würmian (Weichselian) proglacial sediments from
Switzerland: methodological aspects and stratigraphical conclusions. Boreas 36:130-142

Preusser F, Degering D, Fuchs M, Hilgers A, Kadereit A, Klasen N, Krbetschek MR, Richter D, Spencer J (2008) Luminescence dating: Basics, methods and applications. E\&G Quat Sci J 57:95-149

Preusser F, Chithambo ML, Götte T, Martini M, Ramseyer K, Sendezera EJ, Susino GJ, Wintle AG (2009) Quartz as a natural luminescence dosimeter. Earth-Sci Rev 97:196-226

Preusser F, Reitner J, Schlüchter C (2010) Distribution, geometry, age and origin of overdeepened valleys and basins in the Alps and their foreland. Swiss J Geosci 103:407-426

Preusser F, Graf HR, Keller O, Krayss E, Schlüchter C (2011) Quaternary glaciation history of northern Switzerland. E\&G Quat Sci J 60:282-305

Preusser F, May JH, Eschbach D, Trauerstein M, Schmitt L (2016) Infrared Stimulated Luminescence dating of 19th century fluvial deposits from the Upper Rhine River. Geochronometria 43:131-142

Przyrowski R, Schäfer A (2015) Quaternary fluvial basin of northern Upper Rhine Graben. Z Dt Ges Geowiss (german j Geol) 166:71-98

Qin J, Chen J, Li Y, Zhou L (2018) Initial sensitivity change of K-feldspar pIRIR signals due to uncompensated decrease in electron trapping probability: evidence from radiofluorescence measurements. Rad Meas 120:131-136

Reille M, de Beaulieu JL (1995) Long pleistocene pollen records from the praclaux Crater, South-Central France. Quat Res 44:205-215

Richter D, Richter A, Dornich K (2015) Lexsyg smart-a luminescence detection system for dosimetry, material research and dating application. Geochronometria 42:202-209

Saxton KE, Rawls WJ (2006) Soil water characteristic estimates by texture and organic matter for hydrologic solutions. Soil Sci Soc Am J 70:1569-1578

Scheidt S, Hambach U, Rolf C (2015) A consistent magnetic polarity stratigraphy of late Neogene to Quaternary fluvial sediments from the Heidelberg Basin (Germany): a new time frame for the Plio-Pleistocene palaeoclimatic evolution of the Rhine Basin. Glob Planet Change 127:103-116

Schlüchter C (1988) A non-classical summary of the Quaternary stratigraphy in the northern Alpine Foreland of Switzerland. Bull Soc Neuchâtel Géograph 32:143-157

Schlüchter C (1989a) The most complete Quaternary record of the Swiss Alpine Foreland. Palaeogeogr Palaeoclimatol Palaeoecol 72:141-146

Schlüchter C (1989b) Thalgut: Ein umfassendes eiszeitstratigraphisches Referenzprofil im nördlichen Alpenvorland. Eclogae Geol Helv 82:277-284

Schmidt C, Friedrich J, Adamiec G, Chruscinska A, Fasoli M, Kreutzer S, Martini M, Panzeri L, Polymeris GS, Przegietka K, Valla PG, King GE, Sanderson DCW (2018) How reproducible are kinetic parameter constraints of quartz luminescence? : an interlaboratory comparison for the $110^{\circ} \mathrm{C}$ TL peak. Rad Meas 110:14-24

Siegenthaler C, Huggenberger P (1993) Pleistocene Rhine gravel: deposits of a braided river system with dominant pool preservation. Best JL, Bristow CS (Eds.). Braided Rivers. Geol Soc 75:147-162

Stephan HJ (2014) Climato-stratigraphic subdivision of the Pleistocene in Schleswig-Holstein, Germany and adjoining areas. E\&G Quat Sci J 63:3-18

Thiel C, Buylaert JP, Murray AS, Terhorst B, Hofer I, Tsukamoto S, Frechen M (2011) Luminescence dating of the Stratzing loess profile (Austria) - Testing the potential of an elevated temperature post-IR IRSL protocol. Quat Int 234:23-31

Thierion C, Longuevergne L, Habets F, Ledoux E, Ackerer P, Majdalani S, Leblois E, Lecluse S, Martin E, Queguiner S, Viennot P 
(2012) Assessing the water balance of the Upper Rhine Graben hydrosystem. J Hydrol 424-425:68-83

Thomsen KJ, Murray AS, Jain M, Bøtter-Jensen L (2008) Laboratory fading rates of various luminescence signals from feldspar-rich sediment extracts. Rad Meas 43:1474-1486

Urban B, Sierralta M, Frechen M (2011) New evidence for vegetation development and timing of Upper Middle Pleistocene interglacials in Northern Germany and tentative correlations. Quat Int 241:125-142

Valet JP, Bassinot F, Simon Q, Savranskaia T, Thouveny N, Bourlés DL, Villedieu A (2018) Constraining the age of the last geomagnetic reversal from geochemical and magnetic analyses of Atlantic, Indian, and Pacific Ocean sediments. Earth Planet Sci Lett 506:323-331

van Husen D, Reitner JM (2011) An outline of the Quaternary Stratigraphy of Austria. E\&G Quat Sci J 60:366-387

Walling J, Murray AS, Duller G (2000) Underestimation of equivalent dose in single-aliquot optical dating of feldspar caused by preheating. Rad Meas 32:691-695

Weidenfeller M, Knipping M (2008) Correlation of Pleistocene sediments from boreholes in the Ludwigshafen area, western Heidelberg Basin. E\&G Quat Sci J 57:270-285
Welten M (1988) Neue pollenanalytische Ergebnisse über das Jüngere Quartär des nördlichen Alpenvorlandes der Schweiz (Mittel- und Jungpleistozän). Beitr Geol Karte Schweiz N.F. pp. 162:40

Wintle AG, Murray AS (2006) A review of quartz optically stimulated luminescence characteristics and their relevance in single-aliquot regeneration dating protocols. Rad Meas 41:369-391

Zagwijn W (1985) An outline of the Quaternary stratigraphy of the Netherlands. Geol En Mijnb 64:17-24

Zagwijn W (1992) The beginning of the Ice Age in Europe and its major subdivisions. Quat Sci Rev 11:583-591

Zhang J (2017) Behavior of the electron trapping probability change in IRSL dating of K-feldspar: a dose recovery study. Quat Geochron 44:38-46

Zhang J, Li SH (2020) Review of the post-IR IRSL dating protocols of K-Feldspar. Methods Protoc 3:7

Ziegler PA (1994) Cenozoic rift system of Western and Central Europe: an overview. Geol En Mijnb 73:99-127 